\title{
Diversity of Testate Amoebae as an Indicator of the Conservation Status of Peatlands in Southwest Europe
}

\author{
Rafael Carballeira ${ }^{1,2, *(1)}$ and Xabier Pontevedra-Pombal ${ }^{2}$ \\ 1 Centro de Investigacións Científicas Avanzadas (CICA), Facultade de Ciencias, Universidade da Coruña, \\ 15071 La Coruña, Spain \\ 2 Departamento de Edafoloxía e Química Agrícola, Facultade de Bioloxía, Universidade de Santiago de \\ Compostela, 15782 Santiago de Compostela, Spain; xabier.pombal@usc.es \\ * Correspondence: rafael.carballeira@gmail.com or r.carballeira@udc.es
}

check for updates

Citation: Carballeira, R.;

Pontevedra-Pombal, X. Diversity of Testate Amoebae as an Indicator of the Conservation Status of Peatlands in Southwest Europe. Diversity 2021, 13, 269. https://doi.org/10.3390/ d13060269

Academic Editors: François Munoz,

Mariusz Lamentowicz and

Michael Wink

Received: 29 March 2021

Accepted: 14 June 2021

Published: 15 June 2021

Publisher's Note: MDPI stays neutral with regard to jurisdictional claims in published maps and institutional affiliations.

Copyright: (C) 2021 by the authors. Licensee MDPI, Basel, Switzerland. This article is an open access article distributed under the terms and conditions of the Creative Commons Attribution (CC BY) license (https:/ / creativecommons.org/licenses/by/ $4.0 /)$.

\begin{abstract}
Testate amoebae are one of the most studied groups of microorganisms in Sphagnum peatland ecosystems and, therefore, one of the most reliable bioindicators of their ecological status. Peatland ecosystems are supported by a delicate biogeochemical balance that leads to the formation of peat, one of the main sinks of $C$, as a result of soil-atmosphere interaction, but currently they are one of the most threatened wetland types at their southern distribution limit. In the European continent, where climatic conditions limit peat formation, they have endured significant anthropic pressure for centuries, and the risk of loss of biodiversity linked to these ecosystems is critical. In addition, peatlands are poorly known ecosystems in the Iberian Peninsula compared with other wetlands; therefore, we have studied the chemical parameters of water and the diversity patterns of testate amoebae in the western Iberian Peninsula to better understand the current status of these ecosystems. The analysis of testate amoeba communities showed an inverse relationship between the diversity and conservation status of these peatlands, both in relation to chemical parameters (i.e., $\mathrm{pH}$, electrical conductivity, phosphates) and to the proportion of anthropized area, with a marked geographical pattern in the degree of anthropogenic disturbance.
\end{abstract}

Keywords: testate amoebae; diversity; human impact; peatlands water chemistry; southern Europe

\section{Introduction}

Peatland ecosystems develop as a result of a complex biogeochemical balance, generating a sink for atmospheric $\mathrm{C}$ as a result of the soil-atmosphere interaction [1-3]. However, the disruption of peat generation processes due to changes in climatic conditions (e.g., droughts or high temperatures) or anthropic impact (e.g., drainage, nutrient input, peat extraction, and construction of infrastructures) leads to the release of greenhouse gasses due to peat mineralization $[4,5]$. This is especially critical in the context of climate change because of its positive feedback effect on global warming [6]. In addition, the loss of peatland ecosystems has a direct impact on the biodiversity associated with these ecosystems [7]; for this reason, they have been catalogued as a priority habitat of community interest by the Habitats Directive 92/43/EEC of the European Union [8] in order to establish protection areas and promote monitoring programs that guarantee their conservation, especially compromised by climatic conditions in southern Europe due to the greater fragility of the balance that allows for peat formation and due to the limited size and high fragmentation of this type of habitat $[9,10]$.

Testate amoebae are one of the most studied microorganisms in Sphagnum peatlands due to their ubiquity and great diversity, but especially because their close relationship with environmental factors makes them one of the most informative ecological indicators in peatland ecosystems [11-13]. Testate amoebae as predators play a key role in the microbial food web structure, which critically determines the $C$ cycle in semi-aquatic ecosystems $[14,15]$. The high specific diversity of testate amoebae is linked to the microhabitats originated 
by microtopography and the consequent spatial heterogeneity patterns that determine biogeochemical processes, therefore leading to important macro- and microenvironmental gradients [15-18]. Therefore, the composition and structure of testate amoeba communities are highly sensitive to ecological conditions of peatland ecosystems, as shown by numerous studies on ecological succession, seasonal spatio-temporal variability, and interaction between testate amoebae and vegetation [19-27]. For these reasons, testate amoebae are widely used for paleoecology inferences in peatland studies [22,28-31].

The use of testate amoeba diversity as a bioindicator in Sphagnum peatlands constitutes a powerful tool to assess the conservation status of peatland ecosystems and to understand the magnitude of disturbances entailed by anthropogenic impacts and environmental changes [16,22]. In this sense, the study of testate amoeba communities is essential due to the poor knowledge of the current conservation status of Iberian peatland ecosystems [10]. Therefore, we have studied the diversity of testate amoebae in western Iberian peatlands to identify the main chemical parameters of water that determine the composition and structure of testate amoeba communities.

\section{Materials and Methods}

\subsection{Study Site}

A total of 37 peatlands representative of those present in the western Iberian Peninsula were studied in the period between March and June 2017 (Table 1; Figure 1). Of these, 33 peatlands were studied within the context of a program to monitor the ecological conditions of peatlands of Galicia (NW Spain). In addition, four peatlands in the Serra da Estrela (Portugal) were included in this study. Most Iberian peatlands are located in the Atlantic region, followed by the Mediterranean and Pyrenean geographical areas. Fens constitute the predominant peatland typology, while bogs (both raised and blanket bogs) are scarcer and are mainly found in the Atlantic area. The NW Iberian Peninsula is the geographical area with the highest density of peatlands and the highest diversity of peatland typologies [10]. According to the Habitats Directive 92/43/EEC of the European Union [8], twenty-nine are acidic fens (7140), two are blanket bogs (7130), two are raised bogs (7110), two are meso-eutrophic fens (7230), and the para-peaty wetland AG_G5, a 50 -cm-thick organic soil but with a proportion of organic carbon $<15 \%$ [32]. The western Iberian Peninsula is formed by the Iberian Massif, mainly consisting of Paleozoic metamorphosed sedimentary formations intruded by plutonic rocks [33]. Although the dominant lithology is constituted by siliceous rocks, some peatlands are located on local gabbro outcrops, such as CO_ALC, or on ultramafic rocks, such as CA_CF and CA_QUE. The characteristics of the Iberian Peninsula define it as a climatic hotspot in terms of regional modulation of global climate models [34]. The western Iberian Peninsula has a temperate climate with a dry summer season, and average temperatures of the coldest month ranging between 4 and $9{ }^{\circ} \mathrm{C}$. A gradient exists from the NW Iberian Peninsula, which includes most of Galicia and which shows a greater oceanic influence (Csb), with mild temperatures and high rainfall (900-1200 $\mathrm{mm})$, towards the S Iberian Peninsula (Csa), with average temperatures over $22{ }^{\circ} \mathrm{C}$ in the warmest months and with low rainfall $(400-800 \mathrm{~mm})$. However, the effect of the orography and NW-SW orientation of the high mountains of Serra da Estrela, with a maximum elevation of $1993 \mathrm{~m}$ a.s.l., result in higher mean rainfall values (900-1100 mm) due to the interception of oceanic humid air masses that enter the Iberian Peninsula [35]. Finally, anthropogenic impacts and the degrees of transformation of peatland ecosystems have been evaluated in situ by direct observation (i.e., livestock, drainage channels, plantations), and the percentages of the affected area with respect to the total area have been estimated. 
Table 1. Location and typologies of the studied Iberian peatlands.

\begin{tabular}{|c|c|c|c|c|c|c|c|c|c|c|}
\hline \multirow{2}{*}{ Peatlands } & \multirow{2}{*}{ Code } & \multirow{2}{*}{$\begin{array}{c}\text { Locality } \\
\text { (Province) }\end{array}$} & \multirow{2}{*}{ Country } & \multirow{2}{*}{$\begin{array}{c}\text { Geographic } \\
\text { Area }\end{array}$} & \multirow{2}{*}{\multicolumn{2}{|c|}{ EU Habitat Directive }} & \multicolumn{3}{|c|}{ Coordinates (Datum ETRS89) } & \multirow{2}{*}{$\begin{array}{l}\text { Altitude } \\
\text { (m a.s.1.) } \\
\end{array}$} \\
\hline & & & & & & & Huse & UTM X & UTM Y & \\
\hline $\begin{array}{l}\text { Cruz do } \\
\text { Frade (1) }\end{array}$ & CA_CF & $\begin{array}{c}\text { Cariño (A } \\
\text { Coruña, } \\
\text { Galicia) }\end{array}$ & Spain & $\begin{array}{l}\text { Serra da } \\
\text { Capelada } \\
\text { (CA) }\end{array}$ & $\begin{array}{l}\text { Meso- } \\
\text { eutrophic }\end{array}$ & 7230 & $29 \mathrm{~T}$ & 583605 & 4837869 & 530 \\
\hline Queizal (2) & CA_QUE & $\begin{array}{c}\text { Cariño (A } \\
\text { Coruña, } \\
\text { Galicia) }\end{array}$ & Spain & $\begin{array}{l}\text { Serra da } \\
\text { Capelada } \\
\text { (CA) }\end{array}$ & $\begin{array}{l}\text { Meso- } \\
\text { eutrophic }\end{array}$ & 7230 & $29 \mathrm{~T}$ & 584005 & 4837885 & 490 \\
\hline $\begin{array}{l}\text { Rego do } \\
\text { Tremoal (3) }\end{array}$ & X_VRRT & $\begin{array}{c}\text { Abadín } \\
\text { (Lugo, } \\
\text { Galicia) }\end{array}$ & Spain & $\begin{array}{c}\text { Serra do } \\
\text { Xistral }(X)\end{array}$ & $\begin{array}{l}\text { Acidic } \\
\text { fens }\end{array}$ & 7140 & $29 \mathrm{~T}$ & 626494 & 4812597 & 570 \\
\hline $\begin{array}{l}\text { Tremoal de } \\
\text { Penas } \\
\text { Gordas (4) }\end{array}$ & X_TPG & $\begin{array}{c}\text { Abadín } \\
\text { (Lugo, } \\
\text { Galicia) }\end{array}$ & Spain & $\begin{array}{c}\text { Serra do } \\
\text { Xistral (X) }\end{array}$ & $\begin{array}{l}\text { Acidic } \\
\text { fens }\end{array}$ & 7140 & $29 \mathrm{~T}$ & 626534 & 4811601 & 625 \\
\hline $\begin{array}{l}\text { Veiga do } \\
\text { Rial (5) }\end{array}$ & X_VR & $\begin{array}{c}\text { Abadín } \\
\text { (Lugo, } \\
\text { Galicia) }\end{array}$ & Spain & $\begin{array}{c}\text { Serra do } \\
\text { Xistral }(X)\end{array}$ & $\begin{array}{l}\text { Acidic } \\
\text { fens }\end{array}$ & 7140 & $29 \mathrm{~T}$ & 616311 & 4810992 & 750 \\
\hline $\begin{array}{l}\text { Tremoal da } \\
\text { Revolta (6) }\end{array}$ & X_TR & $\begin{array}{c}\text { Abadín } \\
\text { (Lugo, } \\
\text { Galicia) }\end{array}$ & Spain & $\begin{array}{c}\text { Serra do } \\
\text { Xistral }(X)\end{array}$ & $\begin{array}{l}\text { Acidic } \\
\text { fens }\end{array}$ & 7140 & $29 \mathrm{~T}$ & 619398 & 4812159 & 700 \\
\hline $\begin{array}{c}\text { Chao de } \\
\text { Veiga Mol } \\
\text { (7) }\end{array}$ & X_CVM & $\begin{array}{c}\text { O Val- } \\
\text { adouro } \\
\text { (Lugo, } \\
\text { Galicia) }\end{array}$ & Spain & $\begin{array}{c}\text { Serra do } \\
\text { Xistral }(X)\end{array}$ & $\begin{array}{l}\text { Raised } \\
\text { bog }\end{array}$ & 7110 & $29 \mathrm{~T}$ & 620745 & 4822070 & 695 \\
\hline $\begin{array}{l}\text { Tremoal do } \\
\text { Fiuco (8) }\end{array}$ & X_TF & $\begin{array}{c}\text { Abadín } \\
\text { (Lugo, } \\
\text { Galicia) }\end{array}$ & Spain & $\begin{array}{c}\text { Serra do } \\
\text { Xistral (X) }\end{array}$ & $\begin{array}{l}\text { Raised } \\
\text { bog }\end{array}$ & 7110 & $29 \mathrm{~T}$ & 618996 & 4811886 & 700 \\
\hline $\begin{array}{l}\text { Veiga do } \\
\text { Tremoal (9) }\end{array}$ & X_VT & $\begin{array}{c}\text { Abadín } \\
\text { (Lugo, } \\
\text { Galicia) }\end{array}$ & Spain & $\begin{array}{c}\text { Serra do } \\
\text { Xistral (X) }\end{array}$ & $\begin{array}{l}\text { Acidic } \\
\text { fens }\end{array}$ & 7140 & $29 \mathrm{~T}$ & 620106 & 4811318 & 700 \\
\hline $\begin{array}{c}\text { Chao de } \\
\text { Lamoso (10) }\end{array}$ & X_CL & $\begin{array}{c}\text { O Val- } \\
\text { adouro } \\
\text { (Lugo, } \\
\text { Galicia) }\end{array}$ & Spain & $\begin{array}{c}\text { Serra do } \\
\text { Xistral (X) }\end{array}$ & $\begin{array}{c}\text { Blanket } \\
\text { bog }\end{array}$ & 7130 & $29 \mathrm{~T}$ & 617074 & 4817170 & 1020 \\
\hline $\begin{array}{c}\text { Pena da } \\
\text { Cadela (11) }\end{array}$ & X_PC & $\begin{array}{c}\text { Muras } \\
\text { (Lugo, } \\
\text { Galicia) }\end{array}$ & Spain & $\begin{array}{c}\text { Serra do } \\
\text { Xistral (X) }\end{array}$ & $\begin{array}{c}\text { Blanket } \\
\text { bog }\end{array}$ & 7130 & $29 \mathrm{~T}$ & 616449 & 4816677 & 1014 \\
\hline $\begin{array}{c}\text { Rego de } \\
\text { Pena } \\
\text { Grande (12) }\end{array}$ & TC_PG1 & $\begin{array}{l}\text { Xermade } \\
\text { (Lugo, } \\
\text { Galicia) }\end{array}$ & Spain & $\begin{array}{l}\text { Terra Chá } \\
\text { (TC) }\end{array}$ & $\begin{array}{l}\text { Acidic } \\
\text { fens }\end{array}$ & 7140 & $29 \mathrm{~T}$ & 605556 & 4692824 & 480 \\
\hline $\begin{array}{c}\text { Rego de } \\
\text { Pena } \\
\text { Grande (13) }\end{array}$ & TC_PG3 & $\begin{array}{c}\text { Xermade } \\
\text { (Lugo, } \\
\text { Galicia) }\end{array}$ & Spain & $\begin{array}{l}\text { Terra Chá } \\
\quad(\mathrm{TC})\end{array}$ & $\begin{array}{l}\text { Acidic } \\
\text { fens }\end{array}$ & 7140 & $29 \mathrm{~T}$ & 605785 & 4692891 & 485 \\
\hline $\begin{array}{c}\text { Lagoa de } \\
\text { Fabás (14) }\end{array}$ & TC_GZ & $\begin{array}{c}\text { Vilalba } \\
\text { (Lugo, } \\
\text { Galicia) } \\
\end{array}$ & Spain & $\begin{array}{l}\text { Terra Chá } \\
\text { (TC) }\end{array}$ & $\begin{array}{l}\text { Acidic } \\
\text { fens }\end{array}$ & $\begin{array}{l}7140- \\
\text { pond }\end{array}$ & $29 \mathrm{~T}$ & 613605 & 4799346 & 435 \\
\hline $\begin{array}{c}\text { Lagoa de } \\
\text { Alcaián (15) }\end{array}$ & CO_ALC & $\begin{array}{l}\text { Coristanco } \\
\text { (A } \\
\text { Coruña, } \\
\text { Galicia) }\end{array}$ & Spain & $\begin{array}{l}\text { Chairas } \\
\text { Occidentais } \\
\text { (Western } \\
\text { Plains) (CO) }\end{array}$ & $\begin{array}{l}\text { Acidic } \\
\text { fens }\end{array}$ & $\begin{array}{l}7140-6410 \\
\text { Molinea } \\
\text { meadows- } \\
\text { Atlantic } \\
\text { wet heath }\end{array}$ & $29 \mathrm{~T}$ & 520943 & 4775406 & 400 \\
\hline
\end{tabular}


Table 1. Cont.

\begin{tabular}{|c|c|c|c|c|c|c|c|c|c|c|}
\hline \multirow{2}{*}{ Peatlands } & \multirow{2}{*}{ Code } & \multirow{2}{*}{$\begin{array}{l}\text { Locality } \\
\text { (Province) }\end{array}$} & \multirow{2}{*}{ Country } & \multirow{2}{*}{$\begin{array}{c}\text { Geographic } \\
\text { Area }\end{array}$} & \multirow{2}{*}{\multicolumn{2}{|c|}{ EU Habitat Directive }} & \multicolumn{3}{|c|}{ Coordinates (Datum ETRS89) } & \multirow{2}{*}{$\begin{array}{l}\text { Altitude } \\
\text { (m a.s.l.) }\end{array}$} \\
\hline & & & & & & & Huse & UTM X & UTM Y & \\
\hline $\begin{array}{l}\text { Poza do } \\
\text { Lameiro } \\
\quad(16)\end{array}$ & CO_PL & $\begin{array}{l}\text { Lousame } \\
\text { (A } \\
\text { Coruña, } \\
\text { Galicia) }\end{array}$ & Spain & $\begin{array}{c}\text { Chairas } \\
\text { Occidentais } \\
\text { (Western } \\
\text { Plains) (CO) } \\
\end{array}$ & $\begin{array}{l}\text { Acidic } \\
\text { fens }\end{array}$ & 7140 & $29 \mathrm{~T}$ & 515709 & 4733290 & 450 \\
\hline $\begin{array}{c}\text { Rego } \\
\text { Grande (17) }\end{array}$ & BO_B32 & $\begin{array}{l}\text { Toques (A } \\
\text { Coruña, } \\
\text { Galicia) }\end{array}$ & Spain & $\begin{array}{l}\text { Montes do } \\
\text { Bocelo (BO) }\end{array}$ & $\begin{array}{l}\text { Acidic } \\
\text { fens }\end{array}$ & $\begin{array}{l}\text { 7140- } \\
\text { grasslands }\end{array}$ & $29 \mathrm{~T}$ & 581205 & 4759180 & 600 \\
\hline $\begin{array}{c}\text { Río } \\
\text { Ameneiros } \\
(18)\end{array}$ & BO_RA31 & $\begin{array}{l}\text { Toques (A } \\
\text { Coruña, } \\
\text { Galicia) }\end{array}$ & Spain & $\begin{array}{l}\text { Montes do } \\
\text { Bocelo (BO) }\end{array}$ & $\begin{array}{l}\text { Acidic } \\
\text { fens }\end{array}$ & 7140 & $29 \mathrm{~T}$ & 581388 & 4760452 & 705 \\
\hline $\begin{array}{c}\text { Barranqueira } \\
\text { da Devesa } \\
\text { da Graña } \\
(19)\end{array}$ & BA_118.2 & $\begin{array}{l}\text { Boiro (A } \\
\text { Coruña, } \\
\text { Galicia) }\end{array}$ & Spain & $\begin{array}{c}\text { Serra do } \\
\text { Barbanza } \\
\text { (BA) }\end{array}$ & $\begin{array}{l}\text { Acidic } \\
\text { fens }\end{array}$ & 7140 & $29 \mathrm{~T}$ & 505495 & 4727159 & 540 \\
\hline $\begin{array}{c}\text { Rego da } \\
\text { Puntiña (20) }\end{array}$ & BA_118.3 & $\begin{array}{l}\text { Boiro (A } \\
\text { Coruña, } \\
\text { Galicia) }\end{array}$ & Spain & $\begin{array}{c}\text { Serra do } \\
\text { Barbanza } \\
\text { (BA) }\end{array}$ & $\begin{array}{l}\text { Acidic } \\
\text { fens }\end{array}$ & 7140 & $29 \mathrm{~T}$ & 505318 & 4726200 & 555 \\
\hline $\begin{array}{l}\text { Chan das } \\
\text { Brañas (21) }\end{array}$ & BA_118.6 & $\begin{array}{l}\text { Boiro (A } \\
\text { Coruña, } \\
\text { Galicia) }\end{array}$ & Spain & $\begin{array}{c}\text { Serra do } \\
\text { Barbanza } \\
\text { (BA) }\end{array}$ & $\begin{array}{l}\text { Acidic } \\
\text { fens }\end{array}$ & 7140 & $29 \mathrm{~T}$ & 502641 & 4723368 & 650 \\
\hline $\begin{array}{l}\text { Rego das } \\
\text { Brañas (22) }\end{array}$ & BA_118.7 & $\begin{array}{l}\text { Boiro (A } \\
\text { Coruña, } \\
\text { Galicia) }\end{array}$ & Spain & $\begin{array}{c}\text { Serra do } \\
\text { Barbanza } \\
\text { (BA) }\end{array}$ & $\begin{array}{l}\text { Acidic } \\
\text { fens }\end{array}$ & 7140 & $29 \mathrm{~T}$ & 503665 & 4722536 & 525 \\
\hline $\begin{array}{l}\text { Campa dos } \\
\text { Extremeños } \\
\text { (23) }\end{array}$ & ANC_CE1 & $\begin{array}{c}\text { Cervantes } \\
\text { (Lugo, } \\
\text { Galicia) }\end{array}$ & Spain & $\begin{array}{l}\text { Serra dos } \\
\text { Ancares } \\
\text { (ANC) }\end{array}$ & $\begin{array}{l}\text { Acidic } \\
\text { fens }\end{array}$ & 7140 & $29 \mathrm{~T}$ & 675506 & 4743659 & 1615 \\
\hline $\begin{array}{l}\text { As Pontellas } \\
1(24)\end{array}$ & SU_C19 & $\begin{array}{c}\text { A Lama } \\
\text { (Ponteve- } \\
\text { dra, } \\
\text { Galicia) }\end{array}$ & Spain & $\begin{array}{l}\text { Serra do } \\
\text { Suído (SU) }\end{array}$ & $\begin{array}{l}\text { Acidic } \\
\text { fens }\end{array}$ & $7140-7110$ & $29 \mathrm{~T}$ & 554323 & 4696467 & 855 \\
\hline $\begin{array}{l}\text { As Pontellas } \\
2(25)\end{array}$ & SU_C21 & $\begin{array}{c}\text { A Lama } \\
\text { (Ponteve- } \\
\text { dra, } \\
\text { Galicia) } \\
\end{array}$ & Spain & $\begin{array}{l}\text { Serra do } \\
\text { Suído (SU) }\end{array}$ & $\begin{array}{l}\text { Acidic } \\
\text { fens }\end{array}$ & 7140 & $29 \mathrm{~T}$ & 554364 & 4696930 & 860 \\
\hline $\begin{array}{l}\text { Costa de } \\
\text { Uxía (26) }\end{array}$ & SU_C26 & $\begin{array}{c}\text { A Lama } \\
\text { (Ponteve- } \\
\text { dra, } \\
\text { Galicia) }\end{array}$ & Spain & $\begin{array}{l}\text { Serra do } \\
\text { Suído (SU) }\end{array}$ & $\begin{array}{l}\text { Acidic } \\
\text { fens }\end{array}$ & 7140 & $29 \mathrm{~T}$ & 551521 & 4695120 & 820 \\
\hline $\begin{array}{l}\text { As Landras } \\
\text { (27) }\end{array}$ & SU_C32 & $\begin{array}{c}\text { A Lama } \\
\text { (Ponteve- } \\
\text { dra, } \\
\text { Galicia) }\end{array}$ & Spain & $\begin{array}{c}\text { Serra do } \\
\text { Suído (SU) }\end{array}$ & $\begin{array}{l}\text { Acidic } \\
\text { fens }\end{array}$ & 7140 & $29 \mathrm{~T}$ & 553636 & 4696430 & 870 \\
\hline $\begin{array}{l}\text { Brañas da } \\
\text { Groba (28) }\end{array}$ & AG_G5 & $\begin{array}{l}\text { Oia (Pon- } \\
\text { tevedra, } \\
\text { Galicia) }\end{array}$ & Spain & $\begin{array}{l}\text { Serra da } \\
\text { Groba (AG) }\end{array}$ & $\begin{array}{c}\text { Acid } \\
\text { peaty soil }\end{array}$ & $\begin{array}{c}\text { Para- } \\
\text { peaty } \\
\text { wetland }\end{array}$ & $29 \mathrm{~T}$ & 513096 & 4657227 & 525 \\
\hline $\begin{array}{l}\text { A Portela } \\
\text { (29) }\end{array}$ & AG_V10 & $\begin{array}{l}\text { Oia (Pon- } \\
\text { tevedra, } \\
\text { Galicia) }\end{array}$ & Spain & $\begin{array}{l}\text { Serra de Valga } \\
\text { (VA) }\end{array}$ & $\begin{array}{l}\text { Acidic } \\
\text { fens }\end{array}$ & 7140 & $29 \mathrm{~T}$ & 512525 & 4648061 & 350 \\
\hline
\end{tabular}


Table 1. Cont.

\begin{tabular}{|c|c|c|c|c|c|c|c|c|c|c|}
\hline \multirow{2}{*}{ Peatlands } & \multirow{2}{*}{ Code } & \multirow{2}{*}{$\begin{array}{c}\text { Locality } \\
\text { (Province) }\end{array}$} & \multirow{2}{*}{ Country } & \multirow{2}{*}{$\underset{\text { Area }}{\text { Geographic }}$} & \multirow{2}{*}{\multicolumn{2}{|c|}{ EU Habitat Directive }} & \multicolumn{3}{|c|}{ Coordinates (Datum ETRS89) } & \multirow{2}{*}{$\begin{array}{l}\text { Altitude } \\
\text { (m a.s.l.) }\end{array}$} \\
\hline & & & & & & & Huse & UTM X & UTM Y & \\
\hline $\begin{array}{c}\text { Gándaras } \\
\text { de Budiño } \\
\text { (30) }\end{array}$ & LOR_GB & $\begin{array}{c}\text { Porriño } \\
\text { (Ponteve- } \\
\text { dra, } \\
\text { Galicia) }\end{array}$ & Spain & $\begin{array}{l}\text { Louro River } \\
\text { Valley (LOR) }\end{array}$ & $\begin{array}{l}\text { Acidic } \\
\text { fens }\end{array}$ & 7140 & $29 \mathrm{~T}$ & 530591 & 4660889 & 30 \\
\hline $\begin{array}{l}\text { Veiga de } \\
\text { Golpellás } \\
\text { (31) }\end{array}$ & LIR_VB124 & $\begin{array}{l}\text { Calvos de } \\
\text { Randín- } \\
\text { Muíños } \\
\text { (Ourense, } \\
\text { Galicia) }\end{array}$ & Spain & $\begin{array}{l}\text { Limia River } \\
\text { Valley (LIR) }\end{array}$ & $\begin{array}{l}\text { Acidic } \\
\text { fens }\end{array}$ & 7140 & $29 \mathrm{~T}$ & 593321 & 4647552 & 865 \\
\hline $\begin{array}{l}\text { Val de Deus } \\
\text { (32) }\end{array}$ & LIR_VD129 & $\begin{array}{l}\text { Muíños } \\
\text { (Ourense, } \\
\text { Galicia) }\end{array}$ & Spain & $\begin{array}{l}\text { Limia River } \\
\text { Valley (LIR) }\end{array}$ & $\begin{array}{l}\text { Acidic } \\
\text { fens }\end{array}$ & 7140 & $29 \mathrm{~T}$ & 589484 & 4645252 & 875 \\
\hline $\begin{array}{l}\text { Veiga do } \\
\text { Calvelo do } \\
\text { Río (33) }\end{array}$ & LIR_VC32 & $\begin{array}{c}\text { Baños de } \\
\text { Molgas } \\
\text { (Ourense, } \\
\text { Galicia) }\end{array}$ & Spain & $\begin{array}{l}\text { Limia River } \\
\text { Valley (LIR) }\end{array}$ & $\begin{array}{l}\text { Acidic } \\
\text { fens }\end{array}$ & 7140 & $29 \mathrm{~T}$ & 612374 & 4675533 & 520 \\
\hline $\begin{array}{l}\text { Covao da } \\
\text { Clareza (34) }\end{array}$ & E_CC & $\begin{array}{l}\text { Seia } \\
\text { (Beira } \\
\text { Alta) }\end{array}$ & Portugal & $\begin{array}{l}\text { Serra da } \\
\text { Estrela (E) }\end{array}$ & $\begin{array}{l}\text { Acidic } \\
\text { fens }\end{array}$ & 7140 & $29 \mathrm{~T}$ & 617938 & 4466145 & 1820 \\
\hline $\begin{array}{l}\text { Cabeço do } \\
\text { Talao (35) }\end{array}$ & E_CT & $\begin{array}{l}\text { Seia } \\
\text { (Beira } \\
\text { Alta) }\end{array}$ & Portugal & $\begin{array}{l}\text { Serra da } \\
\text { Estrela (E) }\end{array}$ & $\begin{array}{l}\text { Acidic } \\
\text { fens }\end{array}$ & 7140 & $29 \mathrm{~T}$ & 616955 & 4466623 & 1850 \\
\hline $\begin{array}{l}\text { Pedras } \\
\text { Guieiras } \\
(36)\end{array}$ & E_PGU & $\begin{array}{l}\text { Seia } \\
\text { (Beira } \\
\text { Alta) }\end{array}$ & Portugal & $\begin{array}{l}\text { Serra da } \\
\text { Estrela (E) }\end{array}$ & $\begin{array}{l}\text { Acidic } \\
\text { fens }\end{array}$ & 7140 & $29 \mathrm{~T}$ & 614406 & 4468721 & 1590 \\
\hline $\begin{array}{l}\text { Lagoa Seca } \\
\text { (37) }\end{array}$ & E_LS & $\begin{array}{l}\text { Seia } \\
\text { (Beira } \\
\text { Alta) }\end{array}$ & Portugal & $\begin{array}{l}\text { Serra da } \\
\text { Estrela (E) }\end{array}$ & $\begin{array}{l}\text { Acidic } \\
\text { fens }\end{array}$ & 7140 & $29 \mathrm{~T}$ & 616302 & 4469814 & 1625 \\
\hline
\end{tabular}

\subsection{Sampling and Testate Amoeba Extraction}

Testate amoeba samples were collected from the Sphagnum stratum in analogous microhabitats (20- to 30-cm-tall moist Sphagnum hummocks); five spatial replicas were collected in each peatland. The selection criteria for Sphagnum hummocks as the target microhabitat are due to the greater dominance of Sphagnum and the high sensitivity to hydrological alteration, especially to the duration and intensity of the dry period. Testate amoebae were extracted from a volume of $10 \mathrm{~cm}^{3}$ of Sphagnum, using only the section between 5 and $10 \mathrm{~cm}$ below the top of the capitulum, thus avoiding the vertical microdistribution of species in the upper centimeters [11,36]. Moss samples were disaggregated in distilled water and shaken for $10 \mathrm{~min}$ to maximize the release of testate amoebae. Testate amoebae were extracted using a standard sieving method [37] through nested $355 \mu \mathrm{m}$ and $10 \mu \mathrm{m}$ sieves. The sieved size fraction was washed by centrifugation at $900 \times g$ for $5 \mathrm{~min}$ and resuspended in a volume of $5 \mathrm{~cm}^{3}$. Slides were mounted fresh, and a minimum of 200 thecae were counted under light microscopy with a Nikon Eclipse E600 equipped with Plan-Apochromat 40x (N.A. 0.95). The relative abundance of each taxon was calculated as a percentage of the total number of thecae counted. A total of 67 testate amoeba taxa have been found in western Iberian peatlands. The list of testate amoeba taxa and their codes is summarized in Supplementary Table S1, and abundance data (\%) of the main taxa ( $>10 \%$ in at least one peatland) of testate amoeba communities in the western Iberian peatlands are summarized in Supplementary Table S2. 


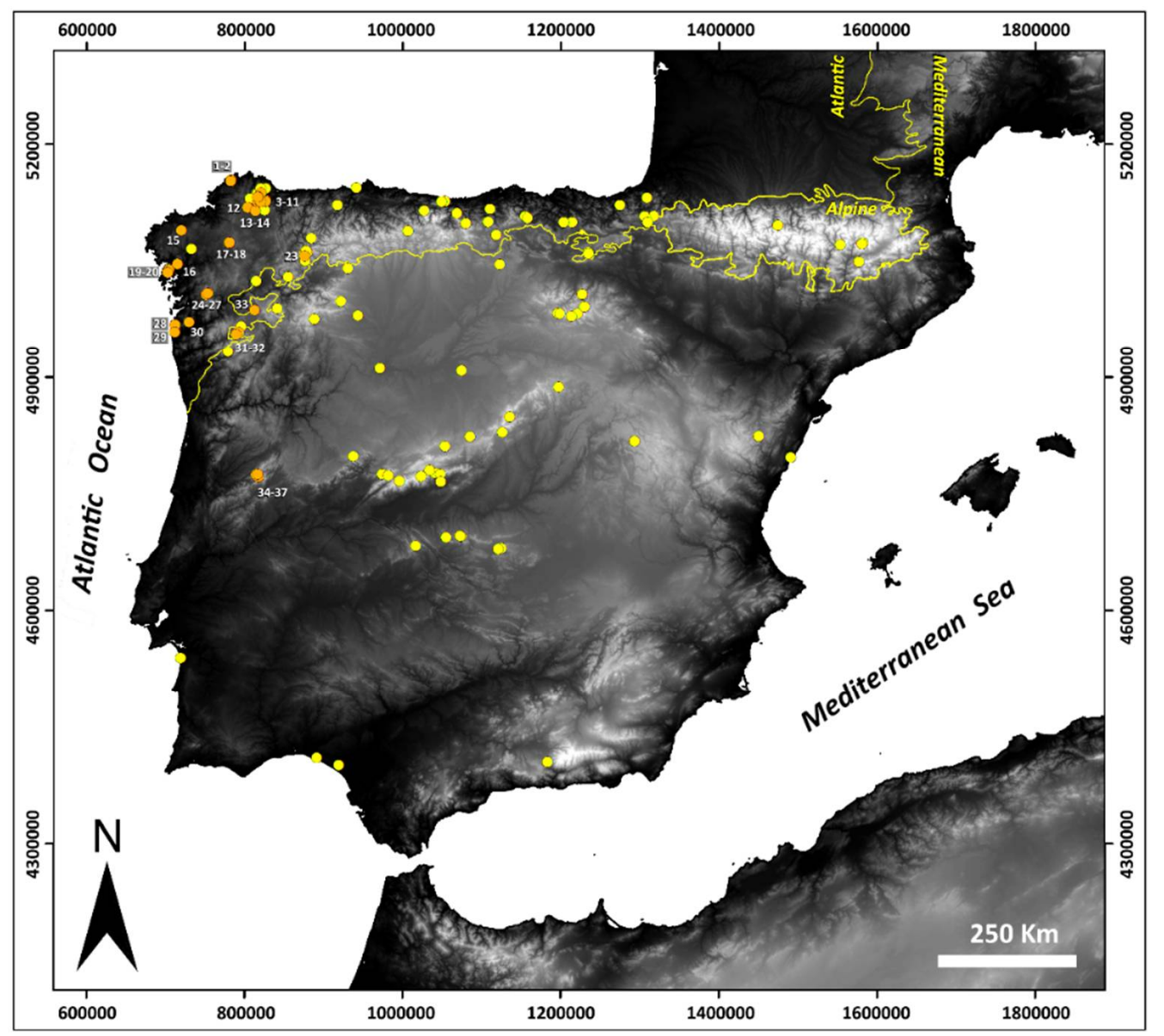

Figure 1. Known peatland ecosystems (yellow) in the Iberian Peninsula (SW Europe) according to Pontevedra-Pombal et al. [10], and locations of the thirty-seven western Iberian peatlands where testate amoeba communities were studied (orange) (Table 1).

\subsection{Water Chemistry Analysis}

Electrical conductivity and $\mathrm{pH}$ were measured in situ using a Hanna HI 98,194 multiparametric probe. Three $50 \mathrm{~mL}$ replicates of water samples for nutrient and cation chemical analysis were collected from water-saturated moss surfaces at the same points where samples for testate amoeba analysis were collected (Table 1; Figure 1). Previously to nutrient sample collection, bottles were treated with $8 \% \mathrm{HNO}_{3}(v / v)$ for $48 \mathrm{~h}$ and repeatedly washed with distilled water. Water samples for nutrient analysis were frozen at $-20{ }^{\circ} \mathrm{C}$ until analysis, and samples for cation determination were kept at $4{ }^{\circ} \mathrm{C}$, avoiding direct sunlight.

Content of cations (calcium and magnesium) in water was measured using a Perkin Elmer 2100 flame atomic absorption spectrometer. Nutrients in water (i.e., nitrate, nitrite, ammonium, and phosphates) were analyzed with an Integral Futura autoanalyzer system (Alliance Instruments), which uses separate analytical lines to determine nitrates, nitrites, and ammonium according to standard colorimetric methods [38]. Total reactive phosphorus was measured in unfiltered water samples using colorimetric methods according to Murphy and Riley [39]. Measurement precision was assessed using relative standard deviation and always remained below 5\%. Detection limits, expressed as three times the standard deviation of 10 replicated measurements of reagent blanks, were $0.28 \mu \mathrm{M}$ for nitrate, $0.10 \mu \mathrm{M}$ for nitrite, $0.10 \mu \mathrm{M}$ for ammonium, and $0.16 \mu \mathrm{M}$ for phosphate. Dissolved inorganic nitrogen (DIN) was calculated from the results obtained for all the inorganic nitrogen sources measured (i.e., DIN = nitrates + nitrites + ammonium). The chemical parameters of peatlands water are summarized in Supplementary Table S3. 


\subsection{Statistical Analysis}

Spatial parameters (i.e., UTM X (m), UTM Y (m), and altitude (m a.s.l.)) have been log-transformed to base 10 so that their orders of magnitude were similar to those of water chemistry data and relative abundances of functional groups for statistical treatment. Calcium and magnesium (meq $\mathrm{L}^{-1}$ ) and nutrients (i.e., nitrate, nitrite, ammonium, and phosphates; $\mu \mathrm{mol} \mathrm{L}{ }^{-1}$ ) were transformed to equivalent stoichiometric units for statistical analysis. The nominal variable "typology" has been coded according to degree of ombrotrophy as follows: para-peaty ecosystems $=5$, meso-eutrophic peatlands $=4$, acidic fens $=3$, raised bogs $=2$, and blanket bogs $=1$. Four functional groups were considered according to Bonnet [40]: mixotrophs (e.g., Amphitrema wrightianum, Archerella flavum, Heleopera sphagnicola, Hyalosphenia papilio), filose (r-strategists) (e.g., Euglypha, Corythion, Trinema), lobose (K-strategists) (e.g., Arcella, Nebela, Centropyxis, Difflugia), and a fourth category called Indifferent, which grouped all other unassigned taxa. Additionally, the L (lobose) to F (filose) ratio was calculated.

The diversity of testate amoeba taxa in each peatland ecosystem was evaluated using the Shannon diversity index $(\mathrm{H})[41]$ :

$$
H=-\sum_{i=1}^{s} p i \ln (p i)
$$

where $p$ is the proportion of the number of individuals within a taxon with respect to the total number of individuals.

The relationship between the three datasets of variables in western Iberian peatlands (i.e., functional groups of testate amoebae, physicochemical parameters of water, and geospatial data) has been explored using Spearman correlation analysis, applying a Student's $t$-test to determine the level of statistical significance of correlations between parameters. Moreover, the datasets were explored using Redundancy Analysis (RDA) to summarize the main patterns of variation in the structure of testate amoeba communities as a function of the dataset of the chemical parameters of the water and environmental variables, considering those taxa with mean abundances greater than $5 \%$ in at least one peatland, or in functional groups that could be explained by the set of main physicochemical variables.

Chemical data, anthropized area, Shannon's diversity index, functional groups of testate amoebae, and L:F ratio were analyzed as a function of the previously defined classes based on the structure of testate amoeba communities, applying the non-parametric Kruskal-Wallis test $(\mathrm{H})$ [42]. Moreover, the affinities among the structures of testate amoeba communities from the thirty-seven peatland ecosystems were analyzed using non-metric multidimensional scaling (NMDS) and the analysis of similarities (ANOSIM) to test the statistical differences between the groups obtained. All statistical analyses were performed using XLSTAT [43], with the exception of NMDS and ANOSIM analysis, which was performed using the vegan package [44] with R [45].

\section{Results}

\subsection{Water Quality}

The $\mathrm{pH}$ showed a statistically significant positive correlation with peatland typology, with acidity increasing from minerotrophic to ombrotrophic conditions, and a decrease in the anthropized area. The $\mathrm{pH}$ range of the studied peatlands was divided according to the three main typologies: (i) $\mathrm{pH} 3.90-4.5$ for blanket bogs and raised bogs (ombrotrophic), (ii) $\mathrm{pH}$ 4.5-5.43 for acidic fens (minerotrophic) and (iii) $\mathrm{pH}$ 5.60-6.79 for meso-eutrophic fens or degraded acidic fens (minerotrophic). The first category (i) includes two blanket bogs (X_PC, X_CL), two raised bogs (X_CVM, X_TF), and two headwater fens (X_VR, TC_PG3). The second category (ii) is comprised of most of the acidic fens studied. The third category (iii) includes two typologies, meso-eutrophic fens on ultramafic rocks, serpentinites (CA_CF, CA_QUE) or gabbros (CO_ALC), and degraded acidic fens with a 
high percentage of human-altered areas, such as TC_GZ, LIR_VB124, and LOR_GB (81.4\%, $33.5 \%$, and $43.8 \%$ of anthropized area, respectively; Table S3).

$\mathrm{pH}$ and phosphates showed a statistically significant positive correlation with electrical conductivity (Supplementary Table S4). The range of electrical conductivity was $<100 \mu \mathrm{S} \mathrm{cm}{ }^{-1}$ in most peatland ecosystems, although it was higher in some peatlands with a high proportion of anthropized area (25.3-100\%), such as TC_GZ $\left(108.72 \mu \mathrm{S} \mathrm{cm}^{-1}\right)$, CO_ALC $\left(111.60 \mu \mathrm{S} \mathrm{cm}^{-1}\right)$, LIR_VD129 $\left(265.00 \mu \mathrm{S} \mathrm{cm}{ }^{-1}\right)$, and LIR_VB124 $\left(325.00 \mu \mathrm{S} \mathrm{cm}{ }^{-1}\right)$. Low calcium and magnesium levels were consistent with low electrical conductivity values, typical of soft waters $\left(<9 \mathrm{mg} \mathrm{L}^{-1}\right)$ (Table S3). Ammonium showed a statistically significant positive correlation with spatial arrangement (UTM Y), and nitrite correlated positively with $\mathrm{pH}$ and anthropized area within the peatland ecosystems, while nitrate did not correlate with any other environmental variables. Therefore, DIN was positively correlated with spatial arrangement (UTM Y) and anthropized area (Table S4). Phosphates ranged from 0.01 to $0.09 \mathrm{mg} \mathrm{L}^{-1}$, and levels of dissolved nitrogen nutrients were low in all peatland ecosystems, with values in the following ranges: nitrates: $0.03-3.98 \mathrm{mg} \mathrm{L}^{-1}$; nitrites: $0.02-0.58 \mathrm{mg} \mathrm{L}^{-1}$; ammonium: $0.02-0.39 \mathrm{mg} \mathrm{L}^{-1}$, and DIN: $0.09-4.10 \mathrm{mg} \mathrm{L}^{-1}$ (Table S3). The anthropized area in peatland ecosystems showed significant correlation with spatial variables, suggesting that the magnitude of the anthropic impact follows a differential geographical pattern, with higher degrees of impact on peatland ecosystems at low altitudes and near the coast than on those located in inland mountain areas, and also linked to DIN inputs (Table S4).

\subsection{Testate Amoeba Assemblages}

Non-metric multidimensional scaling (NMDS) analysis on the structure of testate amoeba communities revealed three significant classes (ANOSIM R $=0.620, p$-value $=0.001$ ): class 1 , mainly composed of the testate amoeba communities in the Suído, Bocelo and Terra Cha peatlands, as well as in the Xistral blanket bogs (X_PC, X_CL) and in fens LIR_VB124 and LIR_VD129; class 2, mainly composed of the testate amoeba communities in the Xistral, Capelada, Ancares, Estrela, and LOR_GB, including fen X_TR and the Xistral raised bogs (X_CVM and X_TF); and class 3, mainly composed of the testate amoeba communities in the fens of Barbanza, CO_ALC and LIR_VC32. Fen CO_PL and para-peaty peatland AG_G5 are highly anthropized and drained ecosystems whose taxa diversity levels were very different from the remaining peatlands studied (Figure 2).

The proportions of the different functional groups in the three cluster classes were the following: 0-5\% mixotrophic taxa, 24-37\% r-strategist taxa, 35-45\% K-strategist taxa, and $18-30 \%$ indifferent taxa. Mixotrophic taxa were absent from class 3 and present in small proportions $(\sim 5 \%)$ in classes 1 and 2 . Meanwhile, the proportions of $\mathrm{r}-$ and $\mathrm{K}-$ strategists were 1:1 in class 2 , while K-strategist taxa were dominant (40-45\%) in classes 1 and 3, although differences were very small (Figure 3). According to peatland typology, testate amoeba communities in blanket bogs (X_PC, X_CL) and in the only raised bog in Suído (SU_C19) were grouped in class 1; those in the Xistral raised bogs (X_CVM, $\mathrm{X}$ _TF) and meso-eutrophic peatlands (CA_CF, CA_QUE) were grouped in class 2, and the communities in the para-peaty ecosystem AG_G5 and in the highly degraded fen CO_PL were not classified (Figure 2).

The composition of testate amoeba communities in peatlands showed low percentages of the dominant taxa due to the important spatial variability within each ecosystem. However, in general, class 1 was dominated by Nebela collaris, with high proportions of Assulina muscorum, Coryhtion dubium, and Euglypha spp., with low L:F ratios (0.52-1.63); class 2 showed co-dominance of Nebela collaris, Assulina seminulum, Heleopera petricola, Centropyxis aculeata, Corythion dubium, and Trinema lineare, with high L:F ratios (0.66-11.6); class 3 was dominated by Centropyxis aerophila, with high proportions of Corythion dubium and Euglypha strigosa and with high L:F ratios (0.78-3.05); and unclassified ecosystems were dominated by Alabasta longicollis, Padaungiella tubulata, and Microcorycia radiata, with 
a high L:F ratio (3.01), in the highly anthropized fen CO_PL and exclusively by the Nebela genus in the para-peaty ecosystem AG_G5, with a high L:F ratio (2.13) (Table S3; Figure 2).

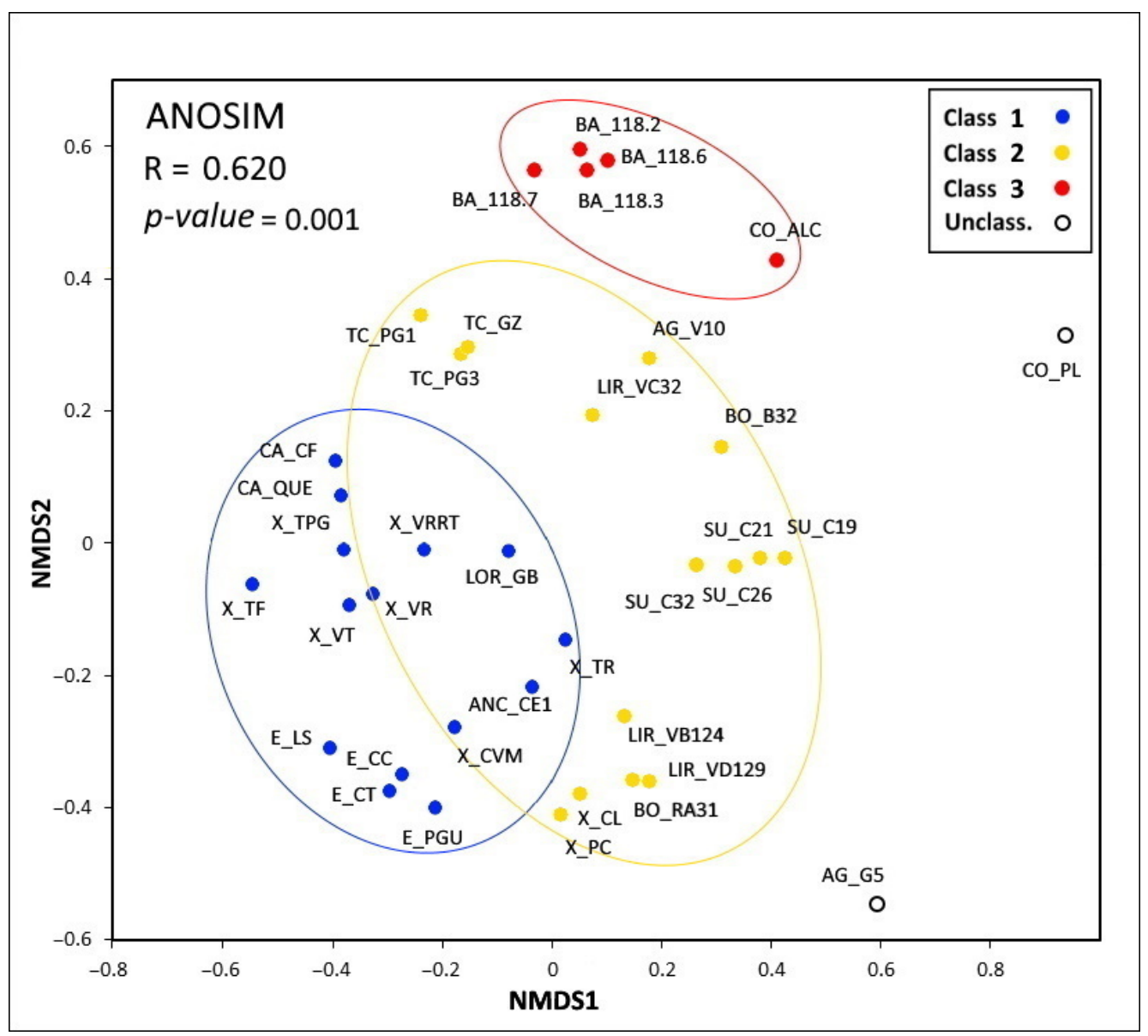

Figure 2. Non-metric multidimensional scaling (NMDS) of the testate amoeba communities in the thirty-seven western Iberian peatlands shows three significant classes: class 1 (Xistral, A Capelada, Ancares, Gándaras de Budiño), class 2 (Xistral (blanket bogs), Terra Chá, Bocelo, Suído, Limia river valley, A Groba), class 3 (Barbanza, CO_ALC), and Unclassified (AG_G5, CO_PL).

Communities of testate amoebae according to peatland types showed some differences with respect to their assigned classes: in the case of Xistral (X_CL, X_PC), blanket bogs included in class 2 had a greater proportion ( $10 \%)$ of mixotrophs (i.e., Amphitrema wrightianum, Heleopera sphagni and Hyalosphenia papilio). However, testate amoeba communities in the meso-eutrophic fens of Capelada (CA_CF, CA_QUE) and in the raised bogs of Xistral (X_CVM, X_TF) and Suído (SU_C19), both of which were included in class 1, did not show any significant differences compared with acidic fens, although, in the latter, differences were found between Sphagnum samples from the ombrotrophic dome and from the marginal fen (Table S2).

Peatland ecosystems as a function of testate amoeba communities showed the following mean altitudes: class $11036.8 \pm 583.8 \mathrm{~m}$ a.s.l. (625-1820), with the exception of the acidic fen Gándaras de Budiño in the Louro River (LOR_GB), located at an altitude of $30 \mathrm{~m}$ a.s.l.; class $2670.8 \pm 197.8 \mathrm{~m}$ a.s.l. (350-875), with the exception of the Xistral blanket bogs, located at $1014 \mathrm{~m}$ a.s.l. (X_PC) and $1020 \mathrm{~m}$ a.s.l. (X_CL); and class $3534 \pm 89.4 \mathrm{~m}$ a.s.1. (400-650). Finally, those unclassified were located at $450 \mathrm{~m}$ a.s.l. (CO_PL) and $525 \mathrm{~m}$ a.s.l. (AG_G5) (Table 1; Figure 2). 

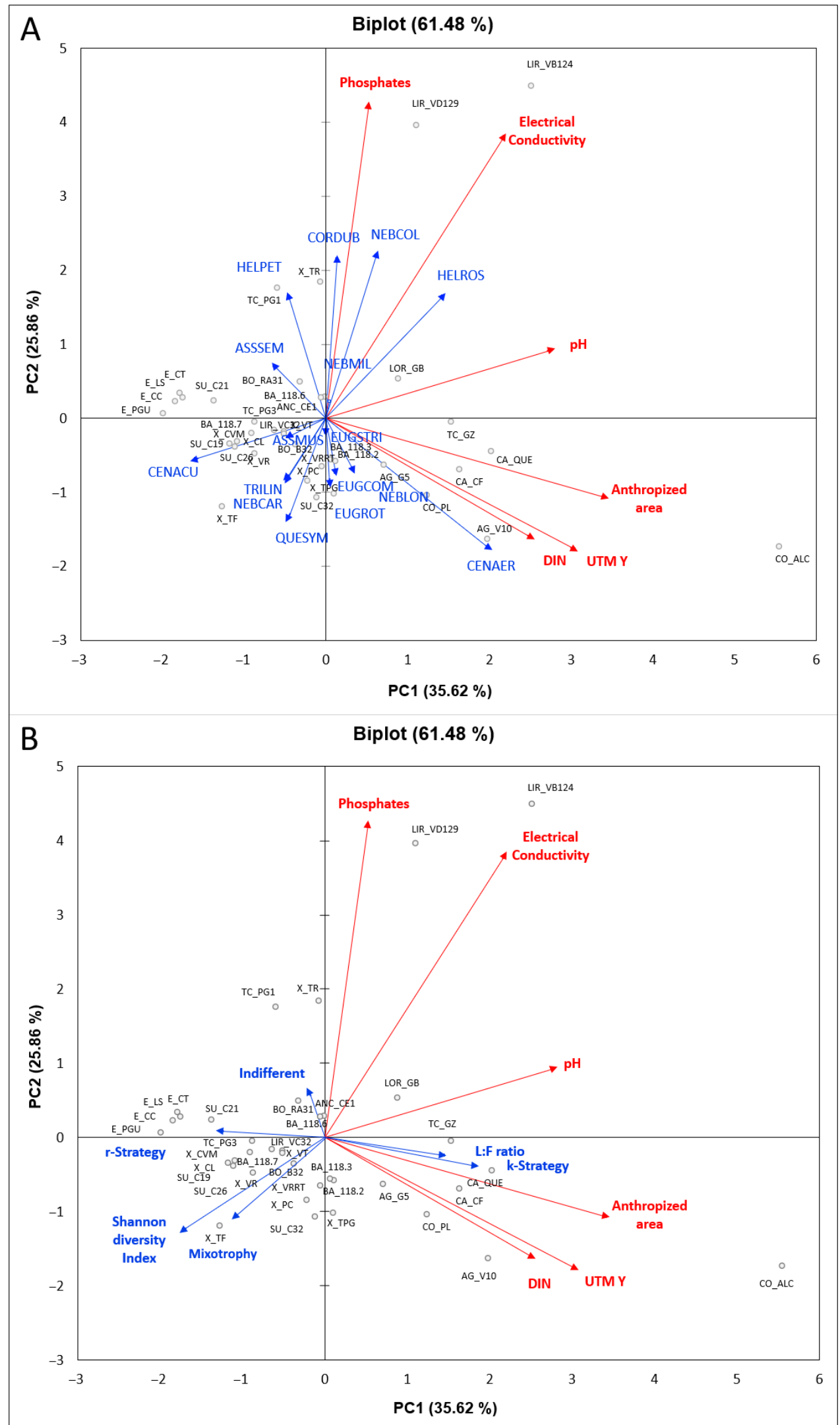

Figure 3. Biplots of the Redundancy Analysis (RDA) performed on the dataset of environmental parameters and testate amoeba community structures in western Iberian peatlands, both based on (A) testate amoeba community structures and (B) testate amoeba functional groups (i.e., K-strategists, r-strategists, mixotrophic, indifferent, L:F ratio and Shannon diversity index). 
The Kruskal-Wallis test on Shannon index values and L:F ratios as a function of the three cluster classes based on testate amoeba communities showed significant differences between class 1 , on one hand, and classes 2 and 3, on the other. The Shannon index showed significantly lower values in class 3 (1.28-2.74) and class 2 (1.45-2.96) than in class $1(2.76-3.55)(\mathrm{H}=23.867 ; p$-value $<0.0001)$. Additionally, L:F ratios were significantly higher in class $2(0.66-11.6)$ and class $3(0.78-3.05)$ than in class $1(0.52-1.63)(\mathrm{H}=16.776$; $p$-value $=0.001)$.

\subsection{Effects of Environmental Variables on the Testate Amoeba Assemblages}

A total of 67 testate amoeba taxa were identified in western Iberian peatland ecosystems (Table S1); the structure of testate amoeba communities is summarized in Table S2. The RDA analysis showed that six environmental variables (i.e., $\mathrm{pH}$, electrical conductivity, DIN, phosphates, UTM Y and anthropized area) explained $61.48 \%$ of the total variance of the structure of testate amoeba communities, both in terms of taxa abundances (Figure 3A) and functional groups, respectively (Figure 3B). All the environmental variables were included in the RDA analysis, with exception of altitude and UTM X because these variables show a poor relationship with the other variables considered in the correlation test, or redundant variables (i.e., calcium and magnesium with electrical conductivity; ammonium, nitrite and nitrate with DIN). The first component (RDA1) explained $35.62 \%$ of the total variability of the dataset, showing an environmental gradient along an axis defined by peatland ecosystems with a higher ombrotrophy and testate amoeba diversity, on one end, and those with increased nutrient levels and minerotrophic conditions, on the other. The Xistral and Serra da Estrela peatland ecosystems had greater testate amoeba diversities, while the peatland ecosystems of Barbanza, A Grova mountains, and Chairas Occidentais (Western Plains) showed increasing degrees of anthropogenic impact, with the poorest water quality and the lowest testate amoeba diversity (Figure 3A,B). The Limia River valley peatlands are mainly coupled to a river system, and water chemical composition was highly influenced by runoff water (Figure 3A,B). The taxa Trinema lineare, Trinema enchelys, Centropyxis aculeata, Hyalosphenia subflava, Euglypha heterospina, Difflugia bryophila, Nebela flabellulum, Amphitrema wrightianum, and Archerella flavum (Figure 3A), and therefore the r-strategist and mixotroph functional groups (Figure 3B), were linked to increased values of the Shannon diversity index and to ombrotrophic conditions.

The second component (RDA2) explained $25.86 \%$ of the total variability of the dataset, which we interpreted as an increase in nutrients and minerotrophic conditions either due to (i) hydrological conditions with a greater runoff contribution (i.e., electrical conductivity, phosphates), and/or (ii) the degree of anthropogenic impact (i.e., pH, DIN, UTM Y, anthropized area) (Figure 3). The abundance of the taxa Nebela collaris, Assulina muscorum, Difflugia sp. 1, Hyalosphenia ovalis, Heleopera rosea, and Heleopera sphagni (Figure 3A) (and, therefore, of the Indifferent functional group) and the L:F ratio (Figure 3B) are linked to the increase in (i) runoff contribution to peatland ecosystems. The taxa Centropyxis aerophila, Difflugia oblonga, Padaungiella tubulata, Alabasta longicollis, Nebela barbata, Nebela militaris, Argynnia crenulata, Euglypha compressa, Euglypha rotunda and Euglypha strigosa (Figure 3A) (and, therefore, the K-strategists functional group; Figure 3B) are linked to the greater magnitude of the (ii) anthropogenic impacts on peatland ecosystems.

The correlation between the variables in the datasets indicates a decrease in the human impact with altitude and along the West-East axis, since the same trend has been observed for the Shannon diversity index; conversely, there was an increase in variables linked to runoff water (i.e., phosphates, electrical conductivity) or to human impact (i.e., pH, DIN, anthropized area) (Table S4; Figure 3). The correlations between functional groups of testate amoebae and environmental datasets also reflected the effect of human impact on peatland ecosystems, with decreasing ratios of mixotrophic and r-strategist (filose) taxa with respect to K-strategist (lobose) taxa and the subsequent increase in the L:F ratio. Mixotrophic taxa positively correlated with the Shannon diversity index and negatively correlated with high trophic conditions of peatlands. Mixotrophic and K-strategist taxa correlated with 
spatial arrangement (i.e., UTM X, UTM Y) and the magnitude of the human disturbance of peatland ecosystems. The proportions of K-strategist taxa correlated positively with anthropized area and negatively with the Shannon diversity index, while r-strategist taxa negatively correlated with phosphates, calcium, and magnesium and, conversely, indifferent taxa positively correlated with the same water chemical parameters (Table S4; Figure 3). The L:F ratio correlated negatively with more ombrotrophic typologies and positively with electrical conductivity and phosphates (Table S4). Therefore, the proportion of K-strategist and indifferent taxa correlated negatively with the proportion of r-strategist and mixotrophic taxa; moreover, the proportion of r-strategist taxa negatively correlated with indifferent taxa (Table S4; Figure 3).

\section{Discussion}

\subsection{Iberian Peatlands Water Chemistry}

The anthropogenic transformation of peatland ecosystems entails both the alteration of the hydrological regime (e.g., drainage for agricultural use or for water supply) and of the geochemical balance of water by increasing $\mathrm{pH}$ and electrical conductivity due to the increased contributions of runoff water and nutrients. However, land uses (e.g., agriculture, livestock, and wastewater discharge) also involve greater nutrient inputs into peatland ecosystems, causing the disruption of complex and fragile biogeochemical cycles in peatlands [46-50]. In addition, experiments on Swedish peatland ecosystems showed that increases in $\mathrm{pH}$, electrical conductivity, dissolved inorganic nitrogen, and phosphorus are associated with the degree of anthropogenic transformation of peatland ecosystems; conversely, a decrease in these parameters has been observed in long-term peatland restoration programs [50].

The water chemistry data measured in western Iberian peatlands were within the range expected for Sphagnum-dominated peatlands [51-53]. $\mathrm{pH}$ is one of the most important chemical parameters of water for the biogeochemistry of peatlands. Water $\mathrm{pH}$ ranges indicate the main source of water: blanket bogs (X_PC, X_CL) and raised bogs (X_CVM, X_TF, SU_C19), with pH ranging between 3.5 and 4.5, are fed exclusively by rainfall, while peatland ecosystems with higher $\mathrm{pH}$ ranges (4.5-7) also receive runoff contributions (Table S3) [54]. $\mathrm{pH}$ in acidic fens, the most common type of peatland, ranges from 4.5 to 5.5, suggesting that their main water sources are rainwater and very weakly mineralized runoff water from headwater mountain streams. In other peatland ecosystems with $\mathrm{pH}$ ranges of 5.5-7, such as para-peaty ecosystems (AG_G5), meso-eutrophic peatlands (CA_QUE, CA_CF), highly anthropized acidic fens (CO_ALC, CO_PL), and fens coupled to rivers (LIR_VB124, LOR_GB) or ponds (TC_GZ), mineralized runoff water is their main water source (Table S3) [54].

The water composition in western Iberian peatlands is fairly similar to that of weakly mineralized soft waters of the western Iberian peninsula $\left(<400 \mu \mathrm{S} \mathrm{cm}^{-1}\right)$, with a primary contribution from oceanic rainwater and a poor contribution of ions from the dominant siliceous lithology [55,56], although their low electrical conductivity ranges $\left(<100 \mu \mathrm{S} \mathrm{cm}^{-1}\right.$; Table S3) are similar to those found in other Iberian fens, such as those in the Sierra Segundera Mountains [46] or the Bassa Nera fen and Tresurco fens complex in the Pyrenees [57,58], as well as to other European and North American peatlands [51-53]. Western Iberian peatlands are very poor in nutrients compared with other peatlands in temperate regions of Europe and North America [51-53], both in terms of phosphorus (phosphates $<0.10 \mathrm{mg} \mathrm{L}^{-1}$ ) and of dissolved inorganic nitrogen (i.e., nitrate $<2.40 \mathrm{mg} \mathrm{L}^{-1}$, nitrite $<0.58 \mathrm{mg} \mathrm{L}^{-1}$, ammonium $<0.39 \mathrm{mg} \mathrm{L}^{-1}$, and DIN $<2.75 \mathrm{mg} \mathrm{L}^{-1}$ ). However, phosphates are linked with electrical conductivity, suggesting the influence of runoff water on peatland water composition (Table S3; Figure 3), very evident in fens associated with the Limia River (LIR_VB124, LIR_VD129). DIN and nitrites are exclusively linked to the anthropized area (Table S4; Figure 3). Traditionally, human impacts on western Iberian peatlands are related to livestock burden (both of cattle and of wild horses) due to the use of green grass as pasture during the summer season, which remains important nowadays in virtually all 
the studied peatlands. The partial drainage of peatlands is due to several causes: hydrological control due to the construction of water supply reservoirs, the construction of infrastructures (Gándaras de Budiño), and, more generally, drainage for agricultural use, particularly important in the desiccation of Lake Alcaián, or, more recently, for tree plantations (i.e., Pinus, Eucalyptus). Both livestock and agriculture, or even hydrological alteration, directly or indirectly cause an increase in nitrogen input in peatlands, impacting ecological processes and the carbon storage function of peatland [59].

Some peatlands with a high proportion of anthropized area showed a deviation from normal electrical conductivity values $\left(>100 \mu \mathrm{S} \mathrm{cm}{ }^{-1}\right.$ ) (i.e., TC_GZ; CO_ALC; LIR_VD129; LIR_VB124) and nutrients, with slightly high mean nitrate (i.e., $X \_T P G=2.56 \mathrm{mg} \mathrm{L}^{-1}$; SU_C32 $=2.80 \mathrm{mg} \mathrm{L}^{-1} ; \mathrm{G}_{-} \mathrm{V} 10=3.98 \mathrm{mg} \mathrm{L}^{-1}$ ) and ammonium (i.e., CA_CF $=0.24 \mathrm{mg} \mathrm{L}^{-1}$; TC_PG1 $=0.21 \mathrm{mg} \mathrm{L}^{-1}$; TC_PG3 $=0.23 \mathrm{mg} \mathrm{L}^{-1}$; TC_GZ $=0.15 \mathrm{mg} \mathrm{L}^{-1}$; CO_ALC $=0.39 \mathrm{mg} \mathrm{L}^{-1}$; BA_SB118.3 $\left.=0.2 \mathrm{mg} \mathrm{L}^{-1}\right)$. Phosphate levels were low in all the western Iberian peatlands $\left(<0.05 \mathrm{mg} \mathrm{L}^{-1}\right)$ (Table S3), similarly to other Iberian fens [46,57,58], although some peatlands coupled to rivers have slightly high levels of phosphates $\left(0.08-0.09 \mathrm{mg} \mathrm{L}^{-1}\right.$; TC_PG1, X_TR, LIR_VB124, and LIR_VD124) with respect to the threshold value of $0.05 \mathrm{mg} \mathrm{L}^{-1}$ of total phosphorus for peatlands to be considered oligotrophic, according to Eurela and Holappa [60] and Malmer [61] based on the study of interactions between water chemistry and peatland vegetation in north-western Europe and in Finland, respectively.

\subsection{Ecological Drivers of Testate Amoeba Communities}

The known diversity of testate amoebae in Iberian peatlands is around one hundred taxa [62-68]; therefore, the number of 67 taxa found in western Iberian peatlands is representative of these ecosystems and widely overlaps with the known testate amoeba fauna of Sphagnum peatlands in Europe [11,12,19,20,26,36,53,69]. Moreover, some rare taxa have not been previously cited in the Iberian Peninsula, such as Microcorycia radiata, Wailesella eboracensis, Corythion asperulum, Amphitrema wrightianum and Nebela flabellulum; the latter two are closely linked to ombrotrophic habitats in European peatland ecosystems [19,70,71]. In addition, the climatic patterns of the Iberian Peninsula establish a SE-NW gradient in terms of the frequency and extension of peatland ecosystems, which are more widely represented in the NW Iberian Peninsula [10]. Abundance peaks of testate amoebae in peatlands have been mainly reported in spring [16,72].

The diversity and structure of testate amoeba communities are closely linked to water availability and water chemistry $[19,26,73,74]$, both of which are in turn influenced by the geographic location of the peatlands, showing affinities that are consistent with the peatland human disturbance pattern along the geographical gradient caused by human impact on the western Iberian landscape (Table S4; Figure 3). Moreover, landscape disturbance and chemical alterations caused by human impact on Sphagnum peatlands have also been reported to inversely relate to the altitudinal gradient in the northern Swiss Alps [11]. Human disturbance of Sphagnum peatland ecosystems is mainly associated with agricultural uses of the landscape, since this usually entails hydrological alterations and a greater water deficit. The greater runoff contribution and increased nutrient levels modify the main chemical parameters of water ( $\mathrm{pH}$, electrical conductivity, and nutrients), therefore causing a substitution of testate amoeba communities (Figure 3), as has been experimentally observed in N- and P-fertilized Sphagnum peatlands or sedge tundra $[36,74]$ and in surface soils subjected to agricultural use [75]. Historically, population density and intensive agricultural activities have been higher in lowlands near coastal areas of Portugal (http: / / www.ine.pt; accessed on 12 February 2021) and in western coastal areas of Galicia (http:/ / www.ine.es; accessed on 12 February 2021). In addition, peat formation and peatland restoration are fragile because the climate in these areas is milder due to the oceanic influence, and summer drought periods are more intense (https:/ / www.meteogalicia.gal/; accessed on 12 February 2021) [76].

Koenig et al. [11] studied testate amoeba taxa in Sphagnum peatlands in relation to altitudinal gradient in the northern Swiss Alps (580-1890 m) and found diverse ecolog- 
ical preferences related to micro-scale rather than meso- or macro-scale environmental conditions. In addition, Mitchell et al. [26] demonstrated a close relationship between the diversity of testate amoebae and the lithology of Sphagnum peatlands at different altitudes in the Italian Alps (1000-2000 m), and Krashevska et al. [77,78] found that testate amoeba communities from litter and soil surfaces in a tropical mountain forest at different altitudes (1000-3000 m) in Ecuador were intimately linked to soil composition and typology with respect to altitudinal patterns. Analogously, Bonnet [79-84] extensively established that testate amoebae showed preferences in terms of the geochemical properties inherent to different soil types.

However, environmental variables can follow pronounced geographical gradients and indirectly influence biogeochemical cycles at micro-scale [11]. Testate amoebae are very sensitive to water availability, as defined by the depth of the water table in Sphagnum peatlands [85-87], but also to the degree of moisture of the moss layer [88]. Therefore, longer water deficit periods in lowlands can be more intense in those microhabitats most exposed to the atmosphere in Sphagnum peatlands, such as hummocks, thus differentially determining the structure of testate amoeba communities [11,53].

The diversity and structure of testate amoeba communities follow a gradient defined by human disturbance in western Iberian peatlands: mixotrophic and filose taxa are linked to optimal ecological peatland conditions, while lobose taxa are linked to a certain degree of human disturbance. Therefore, high L:F ratios are associated with minerotrophic conditions (Figure 4). The results obtained may seem contradictory with the previous assumptions that lobose and filose species are ecological K- and r-strategists, respectively [27,40], and that a high L:F ratio is characteristic of more stable or climax habitats [40]. However, we interpret that these findings are a consequence of drought stress according to the disturbance degree of Sphagnum peatlands, since lobose taxa are more resistant to drought than filose ones $[27,89]$; this could also explain the higher proportion of lobose taxa in blanket bog microhabitats (i.e., X_CL, X_PC), similar to those found in the Suído peatlands (Figure 3).
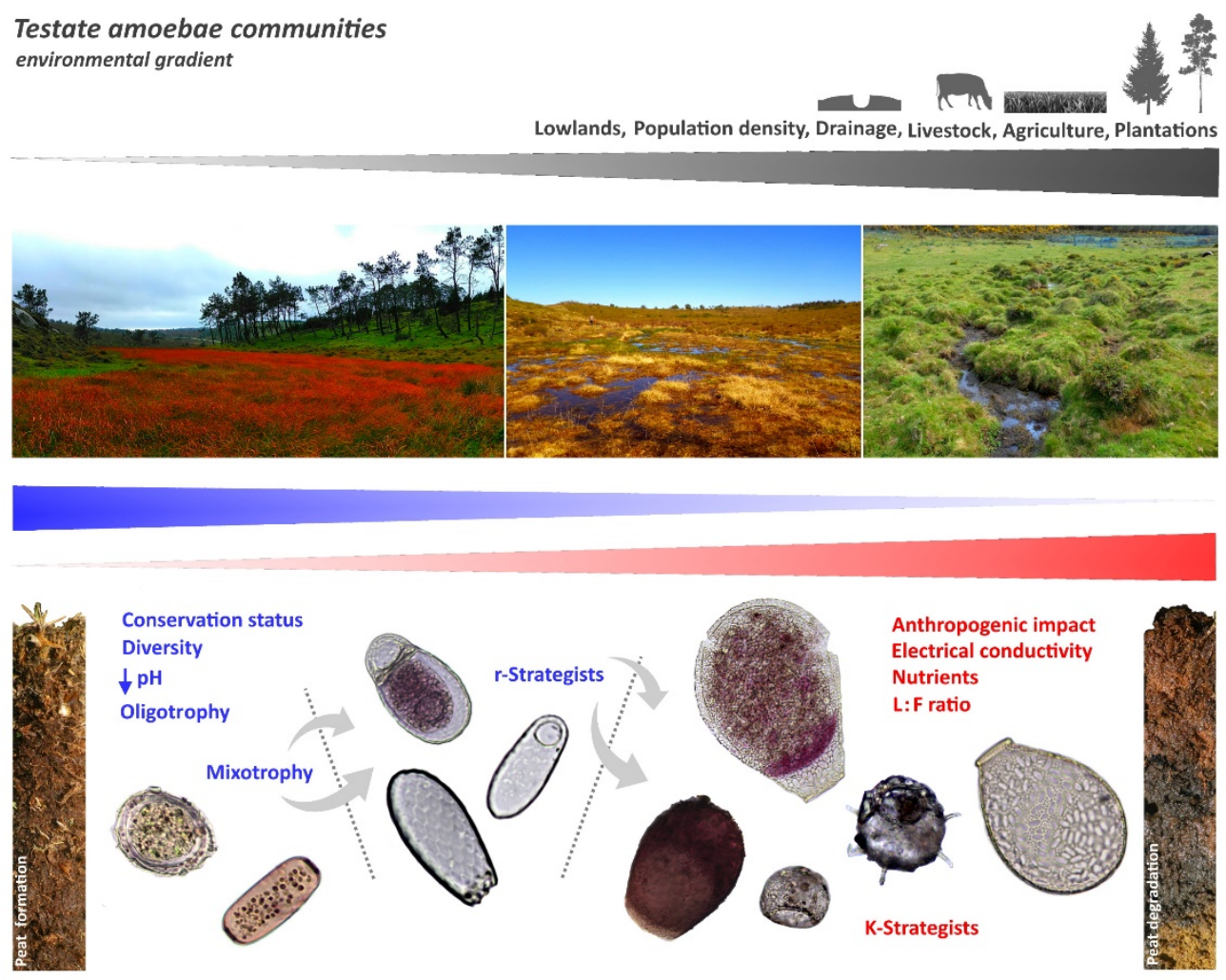

Figure 4. Changes in diversity of testate amoeba communities along the environmental gradient defined by the human disturbance of peatland ecosystems. 
Mixotrophic taxa, especially present in ombrotrophic typologies such as raised and blanket bogs, are linked to the human disturbances of peatland ecosystems, with high diversities and low values for $\mathrm{pH}$, electrical conductivity, nutrients, and proportion of anthropized area (Figure 3). These taxa, which host photosynthetic symbionts (e.g., Amphitrema wrightianum, Archerella flavum, Hyalosphenia papilio, and Heleopera sphagni), have an adaptive advantage in oligotrophic and ombrotrophic conditions $[15,16,74,90,91]$, although H. sphagni also tolerates minerotrophic conditions (Figure 3). These taxa are also characteristic of moist to wet microhabitats and are very rare or absent in dry conditions $[36,68,74]$. A. wrightianum and A. flavum are almost exclusively found on Sphagnum moss in peatland ecosystems [36] and have not been extensively recorded in the Iberian Peninsula, with only two previous records of A. flavum in Sphagnum minerotrophic peatlands in Gándaras de Budiño and Plans de Bohaví (Central Pyrenees) [62-67].

In addition, highly conserved Sphagnum peatlands have a higher proportion of taxa characteristic of humid ombrotrophic conditions, such as mixotrophs and other species like Centropyxis aculeata and large Nebela species [69], such as Nebela flabellulum, a typical species of European Atlantic raised bogs [71]. Higher runoff contributions and P inputs are associated with taxa characteristic of minerotrophic peatlands, such as Centropyxis aerophila, Heleopera petricola, Heleopera rosea, Nebela collaris, and Quadrulella symmetrica, as well as with the replacement of Assulina seminulum by Assulina muscorum under drought stress and in more minerotrophic conditions. Sphagnum peatlands with greater degrees of alteration, higher runoff contributions, high $\mathrm{pH}$ and DIN values, and greater proportions of anthropized area are dominated by Centropyxis aerophila, resistant to desiccation and tolerant to high levels of $\mathrm{N}$ in peatlands $[26,36,69,74]$ (Figure 3). Corythion dubium, Assulina muscorum, Nebela tincta, and Trinema spp., all of them highly tolerant to desiccation and acidic conditions, are commonly found on a wide diversity of mosses outside of peatlands. Nevertheless, they have also been found to be ubiquitous in peatlands as indicators of drought and are dominant in peatlands with deep water tables and in cutover peatlands $[26,36,69]$. Cyphoderia ampulla, Alabasta longicollis, Nebela barbata, and Padaungiella tubulata are taxa linked to Sphagnum in aquatic or wet soil environments $[64,92,93]$, as well as to other soil mosses such as Microcorycia radiata [94], all indicative of para-peaty ecosystems or highly transformed peatlands (i.e., CO_ALC, CO_PL, AG_G5) (Figure 3).

\section{Conclusions}

The diversity of testate amoeba is closely linked to their micro-scale ecological niches, defined by the complex biogeochemical interactions of multiple variables along environmental gradients as a function of the degree of spatio-temporal water saturation. Human use of peatland ecosystems, mainly related to agriculture and water availability, disturbs the hydrological regime and nutrient levels, resulting in an imbalance of the conditions that determine the microhabitats to which testate amoebae are highly sensitive. Water chemistry and testate amoeba community structures change along the geographical gradient defined by the magnitude of human impacts on western Iberian peatlands. Therefore, the diversity of testate amoeba is a good indicator of the ecological optimum and can be applied in ecological studies to estimate the resilience and recovery of peatland ecosystems, as well as at an environmental management level to assess the ecological conservation status of peatlands, especially considering the key role that these ecosystems play in supporting a very unique biodiversity and their geochemical role as carbon sinks in the context of climate change, as well as their fragility due to the climatic conditions at the southern limit of their distribution in southern Europe.

Supplementary Materials: The following are available online at https:/ / www.mdpi.com/article / 10.3390/d13060269/s1, Table S1: List of testate amoeba taxa from Sphagnum samples in the thirtyseven western Iberian peatlands studied. Table S2: Diversity and mean relative abundances of testate amoebae greater than $10 \%$ in at least one peatland ecosystem from Sphagnum samples of the thirty-seven peatlands studied in the western Iberian Peninsula. Table S3: Mean water chemistry data, functional groups and diversity of testate amoeba of the studied Iberian peatlands. Table S4: 
Spearman's correlation coefficients for the environmental variables and testate functional groups of the western Iberian peatlands. Student's $t$-test was used to indicate statistically significant correlations $\left(p\right.$-value $<0.05^{*}$ (orange) $;<0.1 * *$ (yellow) $)$.

Author Contributions: Conceptualization, X.P.-P. and R.C.; Investigation, R.C. and X.P.-P.; Writingoriginal draft preparation, R.C. and X.P.-P.; Writing - review and editing, X.P.-P. and R.C.; Supervision, X.P.-P. All authors have read and agreed to the published version of the manuscript.

Funding: This research was made possible thanks to a grant awarded by the Xunta de Galicia (project: INCITE09-200-019-PR) and thanks to the support of "Consolidación e Estructuración 2018 GRC GI-1243-GEMAP, ED431C 2018/32".

Institutional Review Board Statement: Not applicable.

Informed Consent Statement: Not applicable.

Data Availability Statement: The data are available in supplementary material.

Acknowledgments: We thank Edward Mitchell (Université de Neuchâtel, Switzerland) for responding to our queries and generously checking the identifications of the testate amoebae. We are especially grateful to the reviewers for their suggestions and comments, which have substantially improved this work.

Conflicts of Interest: The authors declare no conflict of interest.

\section{References}

1. Gorham, E. Northern peatlands: Role in the carbon cycle and probably responses to climate warming. Ecol. Appl. 1991, 1, 182-195. [CrossRef]

2. Loisel, J.; Yu, Z.; Beilman, D.W.; Camill, P.; Alm, J.; Amesbury, M.J.; Anderson, D.; Andersson, S.; Bochicchio, C.; Barber, K.; et al. A database and synthesis of northern peatland soil properties and Holocene carbon and nitrogen accumulation. Holocene 2014, 24, 1028-1042. [CrossRef]

3. Leifeld, J.; Menichetti, L. The underappreciated potential of peatlands in global climate change mitigation strategies. Nat. Commun. 2018, 9, 1071. [CrossRef] [PubMed]

4. Moore, T.R.; Knowles, R. Methane emissions from fen, bog, and swamp peatlands in Quebec. Biogeochemistry 1990, $11,45-61$. [CrossRef]

5. Davidson, E.A.; Janssens, I.A. Temperature sensitivity of soil carbon decomposition and feedbacks to climate change. Nature 2006, 440, 165-173. [CrossRef]

6. Shukla, P.R.; Skea, J.; Calvo Buendia, E.; Masson-Delmotte, V.; Pörtner, H.O.; Roberts, D.C.; Zhai, P.; Slade, R.; Connors, S.; van Diemen, R.; et al. An IPCC special report on climate change, desertification, land degradation, sustainable land management, food security, and greenhouse gas fluxes in terrestrial ecosystems. In IPCC, 2019: Climate Change and Land; IPCC: Geneva, Switzerland, 2019.

7. Minayeva, T.Y.; Bragg, O.M.; Sirin, A.A. Towards ecosystem-based restoration of peatland biodiversity. Mires Peat 2017, 1, 1-36.

8. European Commission. European Commission Interpretation Manual of European Union Habitats, Vers. EUR28; European Commission, DG Environment: Brussel, Belgium, 2013; p. 146. Available online: https://ec.europa.eu/environment/nature/legislation/ habitatsdirective/docs/Int_Manual_EU28.pdf (accessed on 15 February 2021).

9. Joosten, H. Mires in Europe: A preliminary status report. Int. Mire Conserv. Group Memb. Newslett. 1997, 3, 10-13.

10. Pontevedra-Pombal, X.; Castro, D.; Carballeira, R.; Souto, M.; López-Sáez, J.A.; Pérez-Díaz, S.; Fraga, M.I.; Valcárcel, M.; García-Rodeja, E. Iberian acid peatlands: Types, origin and general trends of development. Mires Peat 2017, 19, 21.

11. Koenig, I.; Feldmeyer-Christie, E.; Mitchell, E.A.D. Comparative ecology of vascular plant, bryophyte and testate amoeba communities in four Sphagnum peatlands along a altitudinal gradient in Switzerland. Ecol. Indic. 2015, 54, 48-59. [CrossRef]

12. Marcisz, K.; Colombaroli, D.; Jassey, V.E.J.; Tinner, W.; Kołaczek, P.; Gałka, M.; Karpińska-Kołaczek, M.; Słowiński, M.; Mariusz Lamentowicz, M. A novel testate amoebae trait-based approach to infer environmental disturbance in Sphagnum peatlands. Sci. Rep. 2016, 6, 33907. [CrossRef]

13. Niedzwiecki, M.; Mieczan, T.; Adamczuk, M. Ecology of testate amoebae (Protists) in a Sphagnum-dominated peat bog and the relationship between species assemblages and environmental parameters. Oceanol. Hydrobiol. Stud. 2016, 45, 344-352. [CrossRef]

14. Jassey, V.E.J.; Chiapusio, G.; Binet, P.; Buttler, A.; Laggoun-Defarge, F.; Delarue, F.; Bernard, N.; Mitchell, E.A.; Toussaint, M.L.; Francez, A.J.; et al. Above and belowground linkages in Sphagnum peatland: Climate warming affects plant-microbial interactions. Glob. Chang. Biol. 2013, 19, 811-823. [CrossRef]

15. Jassey, V.E.; Signarbieux, C.; Hättenschwiler, S.; Bragazza, L.; Buttler, A.; Delarue, F.; Fournier, B.; Gilbert, D.; Laggoun-Défarge, F.; Lara, E.; et al. An unexpected role for mixotrophs in the response of peatland carbon cycling to climate warming. Sci. Rep. 2015, 5, 16931. [CrossRef] [PubMed] 
16. Heal, O.W. Observations on the Seasonal and Spatial-Distribution of Testacea (Protozoa, Rhizopoda) in Sphagnum. J. Anim. Ecol. 1964, 33, 395-412. [CrossRef]

17. Jassey, V.E.J.; Chiapusio, G.; Mitchell, E.A.D.; Binet, P.; Toussaint, M.L.; Gilbert, D. Fine-sclae horizontal and vertical microdistribution patterns of testate amoebae along a narrow fen/bog gradient. Microb. Ecol. 2011, 61, 374-385. [CrossRef] [PubMed]

18. Basinska, A.M.; Reczuga, M.K.; Gabka, M.; Strózecki, M.; Łuców, D.; Samson, M.; Urbaniak, M.; Lesny, J.; Chojnicki, B.H.; Gilbert, D.; et al. Experimental warming and precipitation reduction affect the biomass of microbial communities in a Sphagnum peatland. Ecol. Indic. 2020, 112, 106059. [CrossRef]

19. Tolonen, K.; Warner, B.G.; Vasander, H. Ecology of Testaceans (Protozoa, Rhizopoda) in mires in South-ern Finland. 2. MultivariateAnalysis. Arch. Protistenkd. 1994, 144, 97-112. [CrossRef]

20. Mitchell, E.A.D.; Borcard, D.; Buttler, A.J.; Grosvernier, P.; Gilbert, D.; Gobat, J.M. Horizontal Distribution Patterns of Testate Amoebae (Protozoa) in a Sphagnum magellanicum Carpet. Microb. Ecol. 2000, 39, 290-300. [PubMed]

21. Davis, S.R.; Wilkinson, D.M. The conservation management value of testate amoebae as 'restoration' indicators: Speculations based on two damaged raised mires in northwest England. Holocene 2004, 14, 135-143. [CrossRef]

22. Mitchell, E.A.D.; Charman, D.J.; Warner, B.G. Testate amoebae analysis in ecological and paleoecological studies of wetlands: Past, present and future. Biodivers. Conserv. 2008, 17, 2115-2137. [CrossRef]

23. Mieczan, T. Ecology of testate amoebae (Protists) in Sphagnum peatlands of eastern Poland: Vertical micro-distribution and species assemblages in relation to environmental parameters. Ann. Limnol. Int. J. Limnol. 2009, 45, 41-49. [CrossRef]

24. Mieczan, T.; Adamczuk, M. Ecology of testate amoebae (Protists) in mosses: Distribution and relation of species assemblages with environmental parameters (King George Island, Antarctica). Polar Biol. 2015, 38, 221-230. [CrossRef]

25. Lamentowicz, M.; Mitchell, E.A.D. Testate amoebae as ecological and palaeohydrological indicators in peatlands-The Polish experience. In Wetlands: Monitoring, Modelling and Management; Okruszko, T., Maltby, E., Szatylowicz, J., Miroslaw-Swiatek, D., Eds.; Taylor \& Francis Group: London, UK, 2007; pp. 85-90.

26. Mitchell, E.A.D.; Bragazza, L.; Gerdol, R. Testate Amoebae (Protista) Communities in Hylocomium splendens (Hedw.) B.S.G. (Bryophyta): Relationships with Altitude, and Moss Elemental Chemistry. Protist 2004, 155, 423-436. [CrossRef]

27. Marcisz, K.; Jassey, V.E.J.; Kosakyan, A.; Krashevska, V.; Lahr, D.J.G.; Lara, E.; Lamentowicz, M.; Macumber, A.; Mazei, Y.; Mitchell, E.A.D.; et al. Testate amoebae functional traits and their use in paleoecology. Front. Ecol. Evol. 2020, 8, 575966. [CrossRef]

28. Charman, D.J. Biostratigraphic and palaeoenvironmental applications of testate amoebae. Quat. Sci. Rev. 2001, 20, 1753-1764. [CrossRef]

29. Turner, T.E.; Swindles, G.T. Ecology of testate amoebae in moorland with a complex fire history: Implications for ecosystem monitoring and sustainable land management. Protist 2012, 163, 844-855. [CrossRef] [PubMed]

30. Qin, Y.; Mitchell, E.A.D.; Lamentowicz, M.; Payne, R.J.; Lara, E.; Gu, Y.; Huang, X.; Wang, H. Ecology of testate amoebae in peatlands of central China and development of a transfer function for paleohydrological reconstruction. J. Paleolimnol. 2013, 50, 319-330. [CrossRef]

31. Lamentowicz, M.; Kajukało-Drygalska, K.; Kołaczek, P.; Jassey, V.E.J.; Gabka, M.; Karpinska-Kołaczek, M. Testate amoebae taxonomy and trait diversity are coupled along an openness and wetness gradient in pine-dominated Baltic bogs. Eur. J. Protistol. 2020, 73, 125674. [CrossRef]

32. Heras-Pérez, P.; Infante-Sánchez, M.; Pontevedra-Pombal, X.; Nóvoa-Muñoz, J.C. Part II, Country chapters: Spain. In Mires and Peatlands of Europe; Joosten, H., Tanneberger, F., Moen, A., Eds.; Schweizerbart Science Publishers: Sttutgart, Germany, 2017; pp. 639-656.

33. Gutiérrez, F.; Gutiérrez, M.; Martín-Serrano, Á. The Geology and Geomorphology of Spain: A Concise Introduction. In Landscapes and Landforms of Spain; Gutiérrez, F., Gutiérrez, M., Eds.; Springer: Dordrecht, The Netherlands, 2014; pp. 1-23.

34. Castro, D.; Souto, M.; Fraga, M.I.; García-Rodeja, E.; Pérez-Díaz, S.; López-Sáez, J.A.; Pontevedra-Pombal, X. High-resolution patterns of palaeoenvironmental changes during the Little Ice Age and the Medieval Climate Anomaly in the northwestern Iberian Peninsula. Geosci. Front. 2020, 11, 1461-1475. [CrossRef]

35. AEMET; IPM. Iberian Climate Atlas; Agencia Estatal de Meteorología: Madrid, Spain; Instituto Portugués de Meteorologia: Lisboa, Portugal, 2011; p. 81.

36. Mitchell, E.A.D.; Gilbert, D. Vertical micro-distribution and response to nitrogen deposition of testate amoebae in Sphagnum. J. Eukaryot. Microb. 2004, 51, 480-490. [CrossRef]

37. Booth, R.K.; Lamentowicz, M.; Charman, D. Preparation and analysis of testate amoebae in peatland paleoenvironmental studies. Mires Peat 2010, 7, 1-7.

38. APHA-AWWA-WEF. Standard Methods for the Examination of Water and Wastewater, 21st ed.; American Public Health Association: Washington, DC, USA, 2005.

39. Murphy, J.; Riley, J.P. A modified single solution method for determination of phosphate in natural waters. Anal. Chim. Acta 1962, 27,31-36. [CrossRef]

40. Bonnet, L. Le peuplement thécamoebien édaphique de la Côte-d'Ivoire. Sols Reg. Lamto Protistol. 1976, 12, 539-554.

41. Shannon, C.E.; Weaver, W. The Mathematical Theory of Communication; University of Illinois Press: Urbana, IL, USA, 1949 ; p. 117.

42. Kruskal, W.H.; Wallis, W.A. Use of ranks in one-criterion variance analysis. J. Am. Stat. Assoc. 1952, 47, 583-621. [CrossRef]

43. XLSTAT. Data Analysis and Statistical Solution for Microsoft Excel Addisonf (XLSTAT Version 2021.2.2); XLSTAT: Paris, France, 2021; Available online: https:/ / www.xlstat.com/ (accessed on 1 March 2021). 
44. Oksanen, J.; Blanchet, F.G.; Kindt, R.; Legendre, P.; Minchin, P.R.; O’hara, R.B.; Simpson, G.L.; Solymos, P.; Henry, M.; Stevens, H.; et al. Community Ecology Package: Ordination, Diversity and Dissimilarities. Version 2013, 2, 295. Available online: https: / / cran.r-project.org; https:/ / github.com/vegandevs/vegan (accessed on 10 January 2021).

45. R Core Team. R: A Language and Environment for Statistical Computing; R Foundation for Statistical Computing: Vienna, Austria, 2020; Available online: https:/ / www.R-project.org/ (accessed on 10 January 2021).

46. Muñoz, J.; Aldasoro, J.J.; Negro, A.; de Hoyos, C.; Vega, J.C. Flora and water chemistry in a relictic mirre complex: The Sierra Segundera mire area (Zamora, NW Spain). Hydrobiologia 2003, 495, 1-16. [CrossRef]

47. Holden, J.; Chapman, P.J.; Labadz, J.C. Artificial drainage of peatlands: Hydrological and hydrochemical process and wetland restoration. Prog. Phys. Geogr. 2004, 28, 95-123. [CrossRef]

48. Luscombe, D.J.; Anderson, K.; Grand-Clement, E.; Gatis, N.; Ashe, J.; Benaud, P.; Smith, D.; Brazier, R.E. How does drainage alter the hydrology of shallow degraded peatlands across multiple spatial scales? J. Hydrol. 2016, 541, 1329-1339. [CrossRef]

49. Menberu, M.W.; Tahvanainen, T.; Marttila, H.; Irannezhad, M.; Bonkanen, A.K.; Penttinen, J.; Klove, B. Water-table-dependent hydrological changes following peatland forestry drainage and restoration: Analysis of restoration success. Water Resour. Res. 2016, 52, 3742-3760. [CrossRef]

50. Lundin, L.; Nilsson, T.; Jordan, S.; Lode, E.; Strömgren, M. Impacts of rewetting on peat, hydrology and water chemical composition over 15 years in two finished peat extraction areas in Sweden. Wetl. Ecol. Manag. 2017, 25, 405-419. [CrossRef]

51. Bourbonniere, R.A. Review of Water Chemistry Research in Natural and Disturbed Peatlands. Can. Water. Resour. J. 2009, 34, 393-414. [CrossRef]

52. Bragazza, L.; Parisod, J.; Buttler, A.; Bardgett, R.D. Biogeochemical plant-soil microbe feedback in response to climate warming in peatlands. Nat. Clim. Chang. 2013, 3, 273-277. [CrossRef]

53. Lamentowicz, M.; Bragazza, L.; Buttler, A.; Jassey, V.E.J.; Mitchell, E.A.D. Seasonal patterns of testate amoeba diversity, community structure and species environment relationships in four Sphagnum-dominated peatlands along a $1300 \mathrm{~m}$ altitudinal gradient in Switzerland. Soil Biol. Biochem. 2013, 67, 1-11. [CrossRef]

54. Rydin, H.; Jeglum, J.K. The Biology of Peatlands; Oxford University Press: Oxford, UK, 2006; pp. 1-296.

55. Alonso, M. Las lagunas de la España peninsular. Limnetica 1998, 15, 1-176.

56. Varela-Silvalde, O.; Castro, D.; Pontevedra-Pombal, X.; Antelo, J. Chemical composition and dynamics of the physico-chemical properties of peatland sub-catchments from the Xistral Mountains (NW Spain). In Challenges and Opportunities in Soil Scienc; Andavira Editora S.L.: Santiago de Compostela, Spain, 2014; pp. 185-189.

57. Pérez-Haase, A.; Ninot, J.M. Hydrological heterogeneity rather than water chemistry explains the high plant diversity and uniqueness of a Pyrenean mixed mire. Folia Geobot. 2017, 52, 143-160. [CrossRef]

58. Colomer, J.; Pérez-Haase, A.; Carrillo, E.; Ventura, M.; Ninot, J.M. Fine-scale vegetation mosaics in Pyrenean mires are driven by complex hydrological regimes and threatened by extreme weather events. Ecohydrology 2018, 12, e2070. [CrossRef]

59. Shi, Y.; Zhang, X.; Wang, Z.; Xu, Z.; He, C.; Sheng, L.; Liu, H.; Wang, Z. Shift in nitrogen transformation in peatland soil by nitrogen inputs. Sci. Total Environ. 2021, 764, 142924. [CrossRef] [PubMed]

60. Eurola, S.; Holappa, K. The Finnish mire type system. Aquil. Ser. Bot. 1985, 21, 101-110.

61. Malmer, N. Vegetational gradients in relation to environmental conditions in northwestern European mires. Can. J. Bot. 1986, 64, 375-383. [CrossRef]

62. Gracia-Royo, M.P. Tecamebas muscícolas del Valle de Ribas (Gerona). Publ. Inst. Biol. Apl. 1964, 37, 67-71.

63. Gracia-Royo, M.P. Tecamebas esfagnícolas de Panticosa (Pirineos Aragoneses). Instituto de Estudios Pirenaicos CSIC Jaca. Actas V Congr. Int. Estud. Pirenaicos 1966, 79, 7-12.

64. Gracia-Royo, M.P. Tecamebas esfagnícolas de la Península Ibérica: Contribución al estudio de las tecamebas (Protozoa, Thecameboidea). Publ. Inst. Biol. Apl. 1972, 52, 5-42.

65. Margalef, R. Datos para la hidrobiología de la Sierra de Guadarrama. Publ. Inst. Biol. Apl. 1949, 6, 5-21.

66. Margalef, R. Comunidades bióticas de las aguas dulces del noroeste de España. Publ. Inst. Biol. Apl. 1955, 21, 137-171.

67. Margalef, R. Algas de agua dulce del noroeste de España. Publ. Instit. Biol. Apli. 1956, 22, 43-152.

68. Pontevedra-Pombal, X.; Carballeira, R.; Crujeiras, U.; García-Rodeja, E. Characterization of testate amoebae in edaphic microhabitats of a histosol of the Serra do Xistral (Galicia). In Soil, a Sustainable Resource for the Bioeconomy; Besga, G., Gartzia, N., Arias, A., Zabaleta, A., Antigüedad, I., Virto, I., Mataiz-Solera, J., Alexandre, C., Eds.; Instituto Vasco de Investigación y Desarrollo Agrario: Donostia, Spain, 2018; pp. 630-633.

69. Mitchell, E.A.D.; Buttler, J.; Warner, B.G.; Gobat, J.M. Ecology of testate amoebae (Protozoa: Rhizopoda) in Sphagnum peatlands in the Jura mountains, Switzerland and France. Ecoscience 1999, 6, 565-576. [CrossRef]

70. Lamentowicz, M.; Mitchell, E.A.D. The ecology of testate amoebae (Protists) in Sphagnum in north-western Poland in relation to peatland ecology. Microb. Ecol. 2005, 50, 48-63. [CrossRef]

71. Kosakyan, A.; Gomaa, F.; Mitchell, E.A.D.; Heger, T.J.; Lara, E. Using DNA-barcoding for sorting out protist species complex: A case study of the Nebela tincta-collaris-bohemica group (Amoebozoa; Arcellinida, Hyalospheniidae). Eur. J. Protistol. 2013, 49, 222-237. [CrossRef] [PubMed]

72. Warner, B.; Asada, T.; Quinn, N. Seasonal influences on the ecology of testate amoebae (Protozoa) in a small Sphagnum peatland in Southern Ontario, Canada. Microb. Ecol. 2007, 54, 91-100. [CrossRef] [PubMed] 
73. Mitchell, E.A.D.; Buttler, A.; Grosvernier, P.; Rydin, H.; Al-binsson, C.; Greenup, A.L.; Heijmans, M.M.P.D.; Hoos-beek, M.R.; Saarinen, T. Relationships among testate amoebae (Protozoa), vegetation and water chemistry in five Sphagnum-dominated peatlands in Europe. New Phytol. 2000, 145, 95-106. [CrossRef]

74. Mitchell, E.A.D. Response of testate amoebae (Protozoa) to N and P fertilization in an Arctic wet sedge tundra. Arct. Antarct. Alp. Res. 2004, 36, 77-82. [CrossRef]

75. Heger, T.J.; Straub, F.; Mitchell, E.A.D. Impact of farming practices on soil diatoms and testate amoebae: A pilot study in the DOK-trial at Therwil, Switzerland. Eur. J. Soil Biol. 2012, 49, 31-36. [CrossRef]

76. Carballeira, A.; Devesa, C.; Retuerto, R.; Santillán, E.; Ucieda, F. Bioclimatología de Galicia; Fundación Pedro Barrié de la Maza Conde de FENOSA: La Coruña, Spain, 1983; p. 250.

77. Krashevska, V.; Bonkowski, M.; Maraun, M.; Scheu, S. Testate amoebae (protista) of an elevational gradient in the tropical mountain rain forest of Ecuador. Pedobiologia 2007, 51, 319-331. [CrossRef]

78. Krashevska, V.; Bonkowski, M.; Maraun, M.; Ruess, L.; Kandeler, L.; Scheu, S. Microorganisms as driving factors for the community structure of testate amoebae along an altitudinal transect in tropical mountain rain forests. Soil Biol. Biochem. 2008, 40, 2427-2433. [CrossRef]

79. Bonnet, L. Les thécamobiens, indicateurs pédologiques, et la notion de climax. Bull. Soc. Hist. Nat. Toulouse 1961, 96, 80-86.

80. Bonnet, L. Le peuplement thécamobiens des sols. Rev. Écol. Biol. Sol 1964, 1, 123-408.

81. Bonnet, L. Le signalement écologique des Thécamoebiens du sol. Bull. Soc. Hist. Nat. Toulouse 1984, 120, 103-110.

82. Bonnet, L. Le signalement écologique des Thécamoebiens du sol (deuxième partie). Bull. Soc. Hist. Nat. Toulouse 1985, 121, 7-12.

83. Bonnet, L. Signalement des préférences écologiques des Thécamoebiens. Bull. Lab. Biol. Quant. 1986, 2, $22-25$.

84. Bonnet, L. Ecologie de quelques Euglyphidae (Thécamoebiens, Filosea) des milieux édaphiques et para édaphiques (Troisième partie: Genre Euglypha). Bull. Soc. Hist. Nat. Toulouse 1992, 128, 11-20.

85. Booth, R.K.; Zygmunt, J.R. Biogeography and comparative ecology of testate amoebae inhabiting Sphagnum-dominated peatlands in the Great Lakes and Rocky Mountain regions of North America. Divers. Distrib. 2005, 11, 577-590. [CrossRef]

86. Booth, R.K. Testate amoebae as proxies for mean annual water-table depth in Sphagnum-dominated peatlands of North America. J. Quat. Sci. 2008, 23, 43-57. [CrossRef]

87. Booth, R.K.; Sullivan, M.E.; Sousa, V.A. Ecology of testate amoebae in a North Carolina pocosin and their potential use as environmental and paleoenvironmental indicators. Ecoscience 2008, 15, 277-289. [CrossRef]

88. Sullivan, M.E.; Booth, R.K. The potential influence of short-term environmental variability on the composition of testate amoeba communities in Sphagnum peatlands. Microb. Ecol. 2011, 62, 80-93. [CrossRef]

89. Beyens, L.; Ledeganck, P.; Graae, B.J.; Nijs, I. Are soil biota buffered against climatic extremes? An experimental test on testate amoebae in arctic tundra (Qeqertarsuaq, West Greenland). Polar Biol. 2009, 32, 453-462. [CrossRef]

90. Bonnet, L. Les thécamoebiens des Bouillouses. Bull. Soc. D'histoire Nat. Toulouse 1958, 93, 529-543.

91. Schönborn, W. Untersuchungen über die Zoochlorellen-Symbiose der Hochmoor-Testaceen. Limnologica 1965, 3, 173-176.

92. Gómez-Sánchez, M.S. Introducción al estudio de los Tecamebidos, (Protozoa) en Asturias. Bol. Cienc. Nat. Inst. Estud. Astur 1980, $25,83-90$.

93. Bankov, N.; Todorov, M.; Ganeva, A. Checklist of Sphagnum-dwelling testate amoebae in Bulgaria. Biodivers. Data J. 2019,6 , e25295. [CrossRef]

94. Török, J. Study on moss-dwelling testate amoebae. Opusc. Zool. 1993, 26, 95-104. 